\title{
Spatial and temporal variation in precipitation isotopes in the Sydney Basin, Australia
}

\author{
Catherine E. Hughes*, Jagoda Crawford \\ Institute for Environmental Research, Australian Nuclear Science and Technology Organisation, Locked Bag 2001, Kirrawee DC, NSW 2232, Australia
}

\section{A R T I C L E I N F O}

\section{Article history:}

Received 1 August 2012

Received in revised form 1 February 2013

Accepted 17 February 2013

Available online 5 March 2013

This manuscript was handled by Laurent

Charlet, Editor-in-Chief, with the assistance

of Ewen James Silvester, Associate Editor

\section{Keywords:}

Precipitation

Stable water isotopes

Oxygen-18

Deuterium excess

Sydney, Australia

Meteoric water line

\begin{abstract}
S U M M A R Y
The $\delta^{2} \mathrm{H}$ and $\delta^{18} \mathrm{O}$ composition of 816 precipitation samples collected between February 2005 and October 2009 from four sites across the Sydney Basin, Australia, were analysed, representing the first published precipitation isotope dataset for the region. Monthly values, weighted averages and local meteoric water lines are presented for use in hydrological applications. The 4 year precipitation weighted average values ranged from $\delta^{2} \mathrm{H}=-20.16 \%, \delta^{18} \mathrm{O}=-4.50 \%$ and $d=15.88 \%$ or Lucas Heights in the coastal region to $\delta^{2} \mathrm{H}=-29.48 \%, \delta^{18} \mathrm{O}=-5.97 \%$ and $d=18.33 \%$ or (Mt Werong in the highlands west of Sydney. For the Sydney Basin as a whole we recommend an overall local meteoric water line of $\delta^{2} \mathrm{H}=8.01 \pm 0.05 \cdot \delta^{18} \mathrm{O}+16.8 \pm 0.3$. Precipitation in the Sydney Basin is isotopically different from the nearest GNIP sites with a significantly higher D-excess. High D-excess values may be the result of low humidity at the sea surface during evaporation at mid latitude sources, however recycling of moisture either locally or along a moisture transport trajectory may also be an important factor. A clear coastal effect was observed but generally temperature and amount effects were found to be weak.
\end{abstract}

Crown Copyright $\odot 2013$ Published by Elsevier B.V. All rights reserved.

\section{Introduction}

The stable isotope $\left(\delta^{2} \mathrm{H}\right.$ and $\left.\delta^{18} \mathrm{O}\right)$ composition of precipitation may be used to provide the precipitation end member for isotopic studies of groundwater and surface water mixing and water balance, to model catchment residence times and flow pathways, as a tracer of moisture sources and rainout processes for regional air-masses, to calibrate isotope-enabled global or regional circulation models or to study land surface interactions or plant water uptake.

The isotopic composition of local precipitation is primarily controlled by regional scale processes, such as weather conditions at the origin of the vapour supply, the trajectory of the water vapour transport and the rainout history of the air mass that results in precipitation at a particular time and place (e.g. Rozanski et al., 1982; Araguas-Araguas et al., 2000; Argiriou and Lykoudis, 2006). At a global scale the relationship between $\delta^{2} \mathrm{H}$ and $\delta^{18} \mathrm{O}$ in precipitation has been defined as $\delta^{2} \mathrm{H}=8.13 \cdot \delta^{18} \mathrm{O}+10.8$ by Rozanski et al. (1993). The relationship can vary from geographic region to region, making it an advantage to establish a local meteoric water line specific to a study area (Simpkins, 1995; Gammons et al., 2006).

\footnotetext{
* Corresponding author. Tel.: +61 29717 9366; fax: +61 297173599.

E-mail addresses: Cath.Hughes@ansto.gov.au (C.E. Hughes), Jagoda.Crawford@ ansto.gov.au (J. Crawford).
}

Previous studies from the mid-latitudes have shown that the correlation between precipitation isotopes and temperature is weaker when sampled on an event or daily basis, compared with monthly or annual timescales (e.g. Treble et al., 2005; Yamanaka et al., 2007; Baldini et al., 2010). For tropical hurricanes the isotopic content of rainfall has been associated with the structure, evolution and the water budget of the system (Gedzelman et al., 2003). However, it has been possible to show a simple linear correlation between the annual mean values of the surface temperature and the ${ }^{18} \mathrm{O}$ composition in high latitude (Dansgaard, 1964).

A world map showing the general patterns of $\delta^{2} \mathrm{H}$ and $\delta^{18} \mathrm{O}$ is maintained by the IAEA (http://nds121.iaea.org/wiser/index.php). An isotope enabled global circulation model (GCM) is presented by Noone and Simmonds (2002a) with a comparison of modelled global $\delta^{18} \mathrm{O}$ with measurements reported in the Global Network of Isotopes in Precipitation (GNIP) database (IAEA/WMO, 2006). More depleted precipitation occurs in the Polar regions due to temperature variations and also as a result of moisture removal as the air mass is transported towards the poles (Araguas-Araguas et al., 2000). High elevation areas have depleted isotopic values due to the altitude effect. Araguas-Araguas et al. (2000) also reported that for oceanic islands and coastal areas located in the inter-tropical regions the precipitation $\delta^{2} \mathrm{H}$ and $\delta^{18} \mathrm{O}$ values were close to those of the ocean. Seasonal variations are observed at mid- and high latitudes, where seasonal variations of temperature are well pronounced. 
The Global Network of Isotopes in Precipitation database contains data on ${ }^{3} \mathrm{H}, \delta^{2} \mathrm{H}$ and $\delta^{18} \mathrm{O}$ in precipitation for seven Australian locations and this data has been analysed by Liu et al. (2010) and Hughes and Crawford (2012). However, Sydney was not originally selected as a GNIP site because of the presence of a nuclear research reactor, which may have had an influence on the tritium results. The nearest long term GNIP sites to Sydney are found in Brisbane $750 \mathrm{~km}$ to the north and Melbourne $700 \mathrm{~km}$ to the south west. Data from this study therefore fills an important gap in the record of $\delta^{2} \mathrm{H}$ and $\delta^{18} \mathrm{O}$ in Australia. Other detailed studies of precipitation isotopes in Australia have been carried out in Melbourne (Barras and Simmonds, 2009) and Tasmania (Treble et al., 2005; Barras and Simmonds, 2008).

This study reports weekly or event based time series of $\delta^{18} \mathrm{O}$, $\delta^{2} \mathrm{H}$ and deuterium excess (D-excess or $\left.d\right)\left(d=\delta^{2} \mathrm{H}-8 \cdot \delta^{18} \mathrm{O}\right.$; Dansgaard, 1964) in precipitation over a 3 to 4 year period at four sites in the Sydney region. A local meteoric water line and precipitation weighted average values are established which can be used for hydrological studies in the region. The seasonal behaviour of the isotopes as well as the relationship between isotope composition and the local surface temperature and precipitation amount are also described.

\section{Site description and climate}

The Sydney Basin is located along the eastern coast of Australia, and is centred on Sydney, Australia's largest city. Apart from the low-lying Cumberland Plain, where Sydney is located, the basin largely consists of an elevated sandstone plateau ranging from $130 \mathrm{~m}$ near the coast to $\sim 650 \mathrm{~m}$ in the southern highlands and rising steeply to over $1000 \mathrm{~m}$ in the Blue Mountains in the west of the basin.

Drinking water for Sydney comes from a series of reservoirs to the west and south of the city fed by catchments in the Southern Highlands and Blue Mountains. Within this region groundwater is used for irrigation and has been considered as an alternative drinking water supply. Significant effort has been invested by the local catchment authority in characterising the isotopic composition of ground waters and surface waters in the Sydney Basin (e.g. SCA and Parsons-Brinckerhoff, 2006), however, this is the first comprehensive study that has been undertaken of the isotopic composition of the precipitation component of the hydrological cycle in the basin.

Four sites were included in this study of precipitation isotopes (Fig. 1; Table 1). Mt Werong and Lithgow in the Blue Mountains, and Big Hill in the Southern Highlands are located in the catchment of Sydney's largest drinking water reservoir, Lake Burragorang. Lucas Heights is situated in a more coastal location on the SW fringe of the Sydney metropolitan area located at the Australian Nuclear Science and Technology Organisation (ANSTO).

The mean annual precipitation and mean annual temperature at the sites is presented in Table 1 . In summer the precipitation predominantly occurs from air masses passing over the warmer east and north-east coast whereas in winter the air masses are more likely to have passed over the cooler south and south-east ocean areas.

The Sydney region has a temperate climate with warm to hot summers. Whilst there is no distinct dry season the wettest months tend to be from January to March (mid-summer to early autumn) with moderate inter-annual rainfall variability. Four large scale climate drivers influence climate on annual to decadal time scales: the Inter-decadal Pacific Oscillation (IPO), Southern Annular Mode (SAM), and El Niño Southern Oscillation (ENSO) and the Indian Ocean Dipole. The effect of these drivers on eastern Australian rainfall is described by Verdon and Franks (2005), Risbey et al.,
2009 and Speer et al. (2011). The IPO in its negative phase brings moist onshore winds at low levels which are important for rain on the eastern side of the ranges and coast. In its negative phase SAM enables dynamic processes that help to create rain systems in southern Australia but is more likely to have a positive correlation with winter and spring precipitation in the Sydney region (Meneghini et al., 2007; Ho et al., 2012). ENSO in the La Niña phase brings moist tropical air to the inland areas of New South Wales (NSW), particularly in winter and spring; La Niña is likely to influence the inland sites in this study more than the coastal site. Verdon and Franks (2005) showed that winter rainfall in eastern Australia is affected by the Indian Ocean Dipole, being higher during years with a negative Dipole Mean Index (DMI), but that variability in sea surface temperature (SST) over Indonesia influences rainfall even when no dipole exists.

A number of meteorological patterns are associated with precipitation in the Sydney region: Large winter and autumn storms in Sydney are commonly associated with East coast lows; intense low pressure systems that form in the Tasman Sea (Speer et al., 2009). Throughout the year cold fronts and inland troughs are a significant contributor to precipitation (Matthews and Geerts, 1995). During the summer convective thunderstorms are a frequent occurrence sometimes accompanied by hail. Occasionally large bands of precipitation that produce infrequent but large events in the north-west of NSW reach the Sydney region.

\section{Methods and data}

\subsection{Sample collection}

Precipitation samples were collected in a sealed high density polyethylene plastic sampling container with a plastic funnel. The sampler was designed with two features (Gröning et al., 2012) to prevent evaporation of the sample or exchange with the atmosphere: (1) a tube connected to the tip of the funnel extended down to the base of the sample so that a small amount of rain would seal the tube, thereby minimising the surface area for evaporation to the atmosphere; and (2) a $5 \mathrm{~m}$ long narrow vent tube was fitted which allows for pressure equalisation in the container. This design was tested over 11 weeks against two other standard collection techniques (i.e. manual composite of daily rain gauge samples as recommended for GNIP sampling at http://wwwnaweb.iaea.org/napc/ih/documents/userupdate/sampling.pdf, and collection in a container with a $1 \mathrm{~cm}$ layer of paraffin oil) to establish its effectiveness at preventing evaporative enrichment. The method compared favourably with the paraffin oil for events above $2 \mathrm{~mm}$ and performed better than collecting daily rain gauge samples overall. Temperature and the delay to collection were the key factors leading to enrichment of samples for small precipitation amounts up to $5 \mathrm{~mm}$.

Precipitation from Lucas Heights was sampled weekly. At the other sites precipitation was sampled on an event basis as interpreted by the volunteer hosting the sampler. Samples were collected in HDPE bottles with the lids closed tightly and taped using electrical tape. The sampler was then dried before redeployment.

$\delta^{2} \mathrm{H}$ and $\delta^{18} \mathrm{O}$ were determined for 816 samples with results expressed in per mille (\%o) using the conventional delta notation relative to VSMOW. Four different laboratories were used to conduct the analyses (the reported lab precision for $\delta^{2} \mathrm{H}$ and $\delta^{18} \mathrm{O}$ respectively is given in \%o following the lab name): University of Waterloo Environmental Isotope Laboratory $(0.8,0.2)$; INSTAAR Stable Isotope Laboratory $(0.6,0.08)$; University of California at Berkeley Center for Stable Isotope Biogeochemistry (1, 0.1); and Alberta Research Council Isotope Hydrology and Geochemistry Laboratory (1, 0.2). 


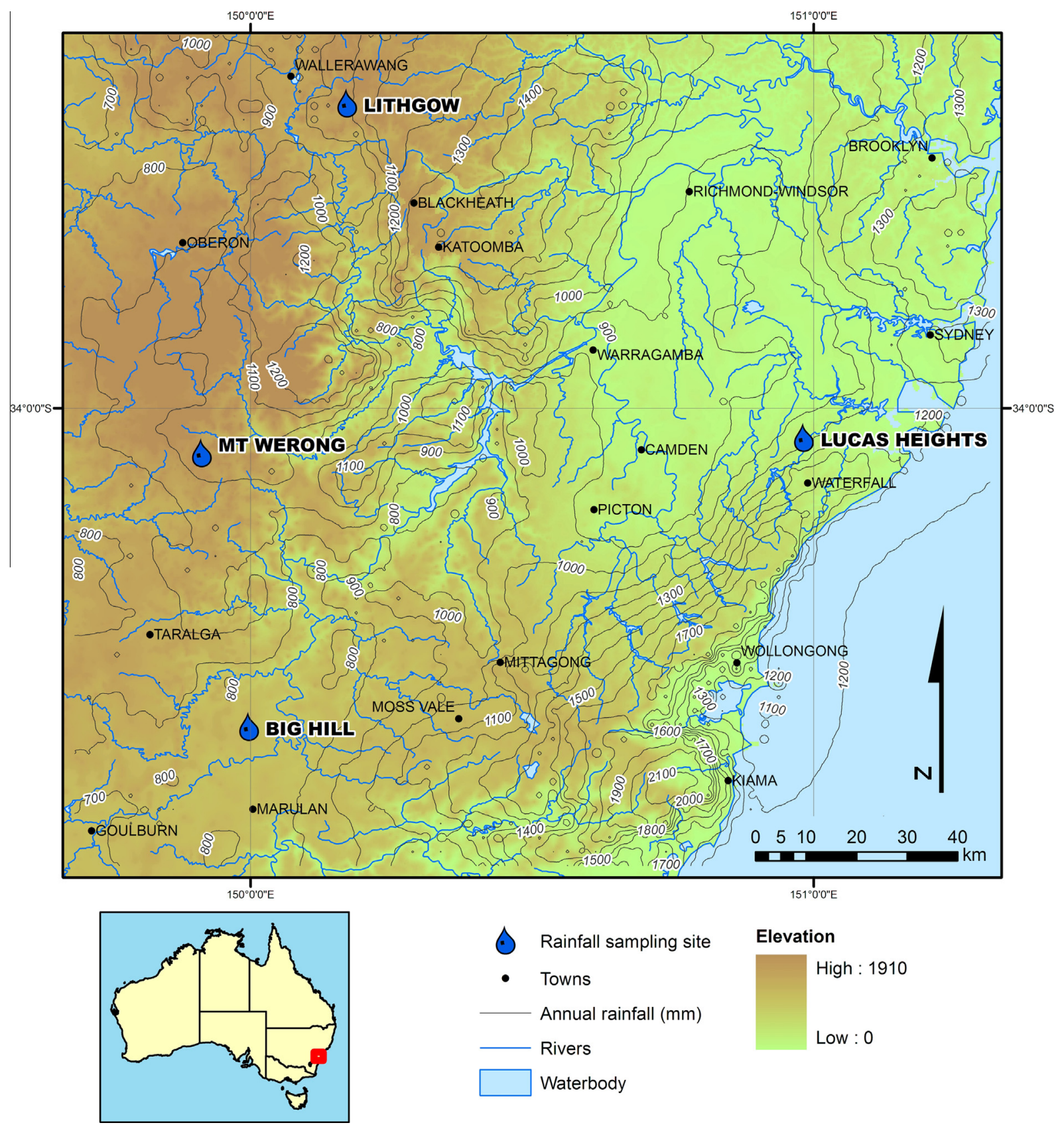

Fig. 1. Sydney region map showing study sites, precipitation contours and topography.

\subsection{Meteorological data}

Meteorological data available varied from site to site and is detailed in Table 2. At Mt Werong, Big Hill and Lucas Heights manual rain gauge measurements were used to determine the precipitation amount corresponding to each sample. Prior to August 2006, Lithgow sample amount was estimated from Bureau of Meteorology (BOM) data sourced $4 \mathrm{~km}$ away; from August 2006 a rain gauge located at the site was used.

\subsection{Data quality assessment}

The number of samples analysed for each site and the percentage of precipitation these represent is given in Table 1. A qualitative quality assessment was applied to each sample based on the results of the sampler comparison experiment, the precipitation amount and intensity and the length of time the sample was stored in the sampler before collection. Samples were assigned to one of three groups: good quality samples (quality code "QC" 1 ), samples with a small chance of fractionation due to low intensity precipitation or delayed collection of small precipitation amounts (QC 4) and those with a fair chance of fractionation either from being in the sampler for a longer period of time or small precipitation amounts, less than $2 \mathrm{~mm}$ (QC 6). Other codes related to sample type or precipitation data type are not relevant here.

Generally samples representing less than $2 \mathrm{~mm}$ were not analysed. Conducting a quality assessment based on the sampling methodology was important to ensure that samples that have potentially been subject to fractionation in the sampler were 
Table 1

Site locations, altitude and distance from the coast. The number of precipitation samples analysed for each site is given in the column labelled " $\mathrm{n}$ ".

\begin{tabular}{|c|c|c|c|c|c|c|c|c|c|c|c|}
\hline Site name & $\begin{array}{l}\text { Latitude } \\
\text { (S) }\end{array}$ & $\begin{array}{l}\text { Longitude } \\
\text { (E) }\end{array}$ & $\begin{array}{l}\text { Elevation } \\
(\mathrm{m})\end{array}$ & $\begin{array}{l}\text { Dist. from } \\
\text { coast }(\mathrm{km})\end{array}$ & $\begin{array}{l}\text { Mean annual } \\
\text { temp }\left({ }^{\circ} \mathrm{C}\right)^{\mathrm{e}}\end{array}$ & $\begin{array}{l}\text { Mean annual } \\
\text { precip. (mm) }\end{array}$ & $\begin{array}{l}\text { Mean no. of } \\
\text { rain days }\end{array}$ & Data period & $n$ & $\begin{array}{l}\text { Total } \\
\text { precip. } \\
(\mathrm{mm})\end{array}$ & $\begin{array}{l}\text { \% Precip. } \\
\text { analysed }\end{array}$ \\
\hline Lucas Heights & -34.05195 & 150.98243 & 152 & 15 & 16.8 & $1012.6^{\mathrm{a}}$ & $87.2^{\mathrm{a}}$ & $\begin{array}{l}16 / 9 / 2005- \\
29 / 9 / 2009\end{array}$ & 133 & 3914 & 99.2 \\
\hline Big Hill & -34.56530 & 149.99707 & 652 & 75 & 12.9 & $699.1^{\mathrm{b}}$ & $88.6^{\mathrm{b}}$ & $\begin{array}{l}25 / 2 / 2005- \\
4 / 10 / 2008\end{array}$ & 118 & 2217 & 96.0 \\
\hline Lithgow & -33.45795 & 150.17124 & 966 & 109 & 11.9 & $858.8^{c}$ & $95.8^{c}$ & $\begin{array}{l}5 / 3 / 2005- \\
5 / 10 / 2008\end{array}$ & 221 & 2795 & 95.4 \\
\hline Mt Werong & -34.07893 & 149.91330 & 1178 & 97 & 9.8 & $984^{\mathrm{d}}$ & $101.2^{\mathrm{d}}$ & $\begin{array}{l}5 / 3 / 2005- \\
27 / 9 / 2009\end{array}$ & 290 & 4184 & 99.3 \\
\hline
\end{tabular}

a 1958-2010 Lucas Heights 066078.

b 1945-2009 Big Hill (Glen Dusk) 070119 (to 2004).

c 1889-2006 Lithgow (Birdwood St.) 063224.

d 1933-2008 Gurnang State Forest (Oberon 063033 (10.3 km NW of Mt Werong station).

e BOM $0.025^{\circ}$ gridded data for $1961-1990$.

Table 2

Details of sampling and meteorological data used in this study. Estimated accuracy of the measurement is shown in square brackets. Data source shown in italics.

\begin{tabular}{|c|c|c|c|c|}
\hline Site Name & $\begin{array}{l}\text { Precipitation stable } \\
\text { isotope data }\end{array}$ & $\begin{array}{l}\text { Precipitation } \\
\text { amount data }\end{array}$ & $\begin{array}{l}\text { Temperature } \\
\text { data }\end{array}$ & $\begin{array}{l}\text { Meteorological } \\
\text { data source }\end{array}$ \\
\hline Lucas Heights & $\begin{array}{l}\text { Weekly composite sample } \\
\text { collected on Tuesday } \\
9 \mathrm{am} .\end{array}$ & 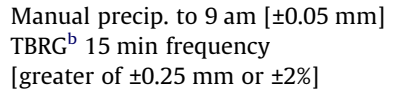 & $\begin{array}{l}- \\
15 \text { minutes at } \\
2 \mathrm{~m}\left[ \pm 0.5^{\circ}\right]\end{array}$ & $\begin{array}{l}\text { ANSTO/BOM }{ }^{\text {a }} \text { Station Lucas Heights (066078) } \\
\text { ANSTO/BOM Station Lucas Heights (066023) }\end{array}$ \\
\hline Mt Werong & $\begin{array}{l}\text { Event based composite } \\
\text { collected after end of } \\
\text { event. Separate snow } \\
\text { samples collected. }\end{array}$ & $\begin{array}{l}\text { Manual precipitation to } 9 \mathrm{am} \text { and } \\
\text { for sample period }[ \pm 0.25 \mathrm{~mm}] \\
\text { TBRG } 1 \mathrm{hr} \text { frequency }[ \pm 0.25 \mathrm{~mm}]\end{array}$ & $\begin{array}{l}\text { Manual daily } \\
\text { high/low to } 9 \text { am } \\
{\left[ \pm 0.5^{\circ}\right]} \\
-\end{array}$ & $\begin{array}{l}\text { On-site measurement } \\
\text { SCA }{ }^{c} \text { Station Mt Werrong (Venns Property) (563050) }\end{array}$ \\
\hline Lithgow & $\begin{array}{l}\text { Event based composite } \\
\text { collected after end of } \\
\text { event. }\end{array}$ & $\begin{array}{l}\text { Manual precipitation for sample } \\
\text { period }[ \pm 0.25 \mathrm{~mm}] \\
\text { Manual precip. to } 9 \text { am }[ \pm 0.05 \mathrm{~mm}] \\
\text { TBRG } 1 \mathrm{hr} \text { frequency }[ \pm 0.25 \mathrm{~mm}]\end{array}$ & $\begin{array}{l}\text { Daily high and } \\
\text { low to } 9 \text { am } \\
{\left[ \pm 0.5^{\circ}\right]} \\
-\end{array}$ & $\begin{array}{l}\text { On-site measurement (from August 2006) } \\
\text { BOM Station Lithgow (Birdwood St) (063224) } 4 \mathrm{~km} \\
\text { WSW (to June 19 2006) BOM Station Lithgow } \\
\text { (Cooerwull) (063226) } 4 \mathrm{~km} \mathrm{SW} \mathrm{(from} \mathrm{June} 202006 \text { ) } \\
\text { SCA Station Lidsdale State Forest (563048) } 11 \mathrm{~km} \mathrm{E} \\
\text { (used for QC only) }\end{array}$ \\
\hline Big Hill & $\begin{array}{l}\text { Daily rain gauge sampled } \\
\text { at } 9 \text { am (to Feb 2006). } \\
\text { Event based or longer } \\
\text { period composite } \\
\text { (from Mar 2006). }\end{array}$ & $\begin{array}{l}\text { Manual precip. to } 9 \text { am }[ \pm 0.13 \mathrm{~mm}] \\
\text { TBRG } 1 \mathrm{hr} \text { frequency }[ \pm 0.25 \mathrm{~mm}] \\
-\end{array}$ & $\begin{array}{l}- \\
- \\
\text { Daily high and } \\
\text { low to } 9 \text { am } \\
{\left[ \pm 0.5^{\circ}\right]}\end{array}$ & $\begin{array}{l}\text { On-site measurement } \\
\text { SCA Station Big Hill (Glen Dusk) (570335) } 0.4 \mathrm{~km} \mathrm{SW} \\
\text { BOM Station Goulburn Airport AWS (070330) } 35 \mathrm{~km} \\
\text { SW }\end{array}$ \\
\hline
\end{tabular}

a $\mathrm{BOM}=$ Bureau of Meteorology.

b TBRG = Tipping bucket rain gauge.

c SCA = Sydney Catchment Authority.

identified on the basis of small precipitation amount, temperature and delay to collection, not by screening based on the data (e.g. low D-excess samples) which may be valid.

Higher frequency tipping bucket rain gauge data were used as a check for manual precipitation measurements and to delineate rainfall events on a less than daily basis. The correlations between daily manual and tipping bucket rain gauge (TBRG) measurements and the ratio of total rainfall amount (manual/ TBRG) respectively were: Lucas Heights $\left(r^{2}=0.96\right.$, ratio $\left.=0.89\right)$, Mt Werong $\left(r^{2}=0.95\right.$, ratio $\left.=1.08\right)$ and Big Hill $\left(r^{2}=0.90\right.$, ratio $=0.97$ ). The use of daily data from a separate site to estimate rainfall amounts at Lithgow introduces an unquantifiable uncertainty on the precipitation amount due to spatial variability during this period ( $n=69,34 \%$ of study precipitation). To determine whether this is likely to have a significant impact on the use of this early data we calculated precipitation weighted meteoric water lines (see Section 4.2) including and excluding the period to July 2006 and found the equations to be almost identical. This gives us confidence in using these rainfall amount estimates for this study.

The different frequency of collection of samples was also considered in terms of its effect on the analyses presented in this paper. In particular, the weekly time step at Lucas Heights results in averaging of consecutive events which, in theory, leads to a reduction in extreme high and low values. To determine how weekly sampling compares with event based sampling the data from Mt Werong was reduced to a weekly precipitation weighted dataset. An overall movement of values towards the average occurs with a corresponding reduction in range of $\delta^{18} \mathrm{O}$ values from $-18.5 \%$ - $4.9 \%$ to $-16.0 \%$ - $1.3 \%$. However, weekly and event based datasets are almost identical in terms of their performance in regressions which confirms that comparison of two sites with slightly different sampling regimes is valid. 


\section{Results and discussion}

\section{1. $\delta^{18} \mathrm{O}, \delta^{2} \mathrm{H}$ and $\mathrm{D}$-excess results}

Time series plots of $\delta^{18} \mathrm{O}$ and precipitation for individual samples are shown in Fig. 2. A seasonal fluctuation of $\delta^{2} \mathrm{H}, \delta^{18} \mathrm{O}$ behaviour is evident with more depleted values in winter. Depleted winter precipitation in the highlands sites (Mt Werong and Lithgow) is often associated with small amounts of snowfall, which occurs at these two sites but not at Lucas Heights or Big Hill during the study period. Lucas Heights data would also be expected to be less depleted than other sites during winter due to higher temperatures and the stronger maritime influence. Large precipitation events may be found throughout the year but are more likely to be seen over the summer months. Summer isotope ratios show the expected increase in comparison with winter values, however there is no clear peak, possibly reflecting the influence of a few large events on the seasonal averages.

The precipitation weighted $\delta^{2} \mathrm{H}, \delta^{18} \mathrm{O}$ and D-excess are shown in Table 3 for a 3 year period where data from all sites were available and then a 4 year period for two sites. There is a decrease in $\delta^{2} \mathrm{H}$ and $\delta^{18} \mathrm{O}$, and an increase in D-excess moving inland from Lucas Heights, located at low altitude near the coast, to Mt Werong which has the highest altitude (Table 1).

The cumulative precipitation weighted average $\delta^{18} \mathrm{O}$, calculated as the amount weighted average of all data prior to and including the sample, is plotted in Fig. 2. It can be used as an indicator of how vulnerable the weighted average estimate is to being influenced by one big event or by a change of season. One large event with a depleted isotopic composition can influence the mean significantly (e.g. June 2007). The change in the average for Lucas Heights and Mt Werong between 3 and 4 years of data (Table 3 ) shows the effect of enriched precipitation throughout the winter and spring of 2009 on the mean. These plots indicate that the weighted isotopic average shows less dependence on the seasonal trend once two or more years of observations are available for its calculation and provide an indicator of how robust averaged values are. Of course longer term trends or cycles of drought may change the average.

The low intensity precipitation that may lead to a quality code of 4 due to the possibility of fractionation inside the sampler also has the potential to be more enriched with a lower D-excess due to evaporation of small raindrops as they fall. For this reason excluding samples based on slightly low D-excess is ill-advised as it potentially excludes valid precipitation of a particular type and may skew the analysis (Hughes and Crawford, 2012). The weighted average values for each quality code for data from all stations are shown in Fig. 3. The values become more enriched from QC 1-6, which is to be expected as the allocation of the codes is influenced by temperature, rainfall amount and intensity, which on their own would be expected to affect enrichment regardless of sampling impacts. Interestingly, the weighted average of samples with QC 6 does not exhibit a notable decrease in D-excess which suggests that overall those samples have not been significantly affected by evaporation.

The monthly amount weighted $\delta^{2} \mathrm{H}, \delta^{18} \mathrm{O}$ were also calculated and are presented in Table 4 . The monthly precipitation weighted amounts were calculated as follows:

$\delta^{2} \mathrm{H}_{\text {month }}=\frac{\sum P_{i} \delta^{2} H_{i}}{\sum P_{i}}$

$\delta^{18} \mathrm{O}_{\text {month }}=\frac{\sum P_{i} \delta^{18} O_{i}}{\sum P_{i}}$

where $P_{i}, \delta^{2} \mathrm{H}_{\mathrm{i}}$ and $\delta^{18} \mathrm{O}_{\mathrm{i}}$ are the precipitation amount, $\delta^{2} \mathrm{H}$ and $\delta^{18} \mathrm{O}$ for sample $i$.

\subsection{Local meteoric water lines (LMWLs)}

Local meteoric water lines were calculated using three regression models: ordinary least squares regression (OLSR), reduced major axis least squares regression (RMA) (IAEA, 1992; Argiriou and Lykoudis, 2006) and precipitation amount weighted least squares regression (PWLSR) (Hughes and Crawford, 2012) (Table 5). It is well known that small precipitation amounts are subject to some evaporation below the cloud base (Dansgaard, 1964). Small precipitation amounts are also vulnerable to fractionation occurring during sampling through evaporation from the funnel and the sample container resulting in enrichment of the residual water. Given that small precipitation amounts are less hydrologically significant we investigate the extent to which the obtained LMWL is influenced by these small precipitation events. This was approached in two ways: removing small precipitation amount samples, and also by using a precipitation weighted least squares regression (Hughes and Crawford, 2012) which maximises the impact of large precipitation events in defining the LMWL. The relationship between $\delta^{2} \mathrm{H}$ and $\delta^{18} \mathrm{O}$ was investigated for all samples and then again by removing samples with QC 6 then QC 4 successively.

A bivariate plot of the $\delta^{2} \mathrm{H}$ against $\delta^{18} \mathrm{O}$, together with a LMWL when the samples of all four sites are combined, is shown in Fig. 3. From Fig. 3 it can be seen that including samples with QC 4 and QC 6 results in a larger sample spread as opposed to only those with QC 1 (represented by yellow filled circles). The Global Meteoric Water Line (GMWL) defined by $\delta^{2} \mathrm{H}=8.13 \cdot \delta^{18} \mathrm{O}+10.8$ (Rozanski et al., 1993) is also presented in the figure and so are two LMWLs for the four sites combined samples (one when QC 1 data is only used and the other for all the data), showing that the LMWL is almost parallel to the GMWL, but with a higher intercept. From Table 5 we see small variations in the slope of the LMWL for the different quality cases considered with small differences between sites. For the precipitation weighted least squares fits Mt Werong consistently shows a larger intercept. The difference in slope between OSLR and PWLSR is only statistically significant (95\% confidence level) for QC 1, 4 and 6 at Mt Werong and when all sites are combined (Table 5). The RMA regression slopes were greater than OLSR slopes in all cases but it varied for PWLSR slopes. The difference of slope between RMA and other regressions was only significant for RMA and PWLSR for all sites combined (95\% confidence level).

A good agreement of both slope and intercept is seen between the OLSR fits when only samples with QC 1 are considered and the PWLSR fit when all samples are used. Generally this represents the highest slope for the OLSR and the lowest slope for the PWLSR. This is an expected result as samples with smaller precipitation amounts (i.e. those with QC 6) have a smaller influence on the fit when the precipitation weighted least squares fitting technique is used. Under Australian conditions these samples often have a lower D-excess due to evaporation which will tend to reduce the slope of the LMWL when using OLSR.

Using the individual samples to construct the LMWL resulted in little difference between the sites, although Mt Werong shows a larger intercept than the other sites. Monthly quantities were also generated from precipitation amount weighted individual samples and LMWLs were generated for the precipitation weighted monthly amounts (Table 5). This is an equivalent to the use of monthly GNIP data to construct a LMWL. Similar slopes and intercepts were obtained to that using the individual samples; once again Mt Werong showed a larger intercept. Overall we recommend a LMWL of $\delta^{2} \mathrm{H}=8.01 \pm 0.05 \cdot \delta^{18} \mathrm{O}+16.8 \pm 0.3$, based on PWLSR for all four sites in the Sydney Basin, for general use in the Sydney region. For specific studies a LMWL from a single site may be more appropriate, depending on elevation, proximity to 

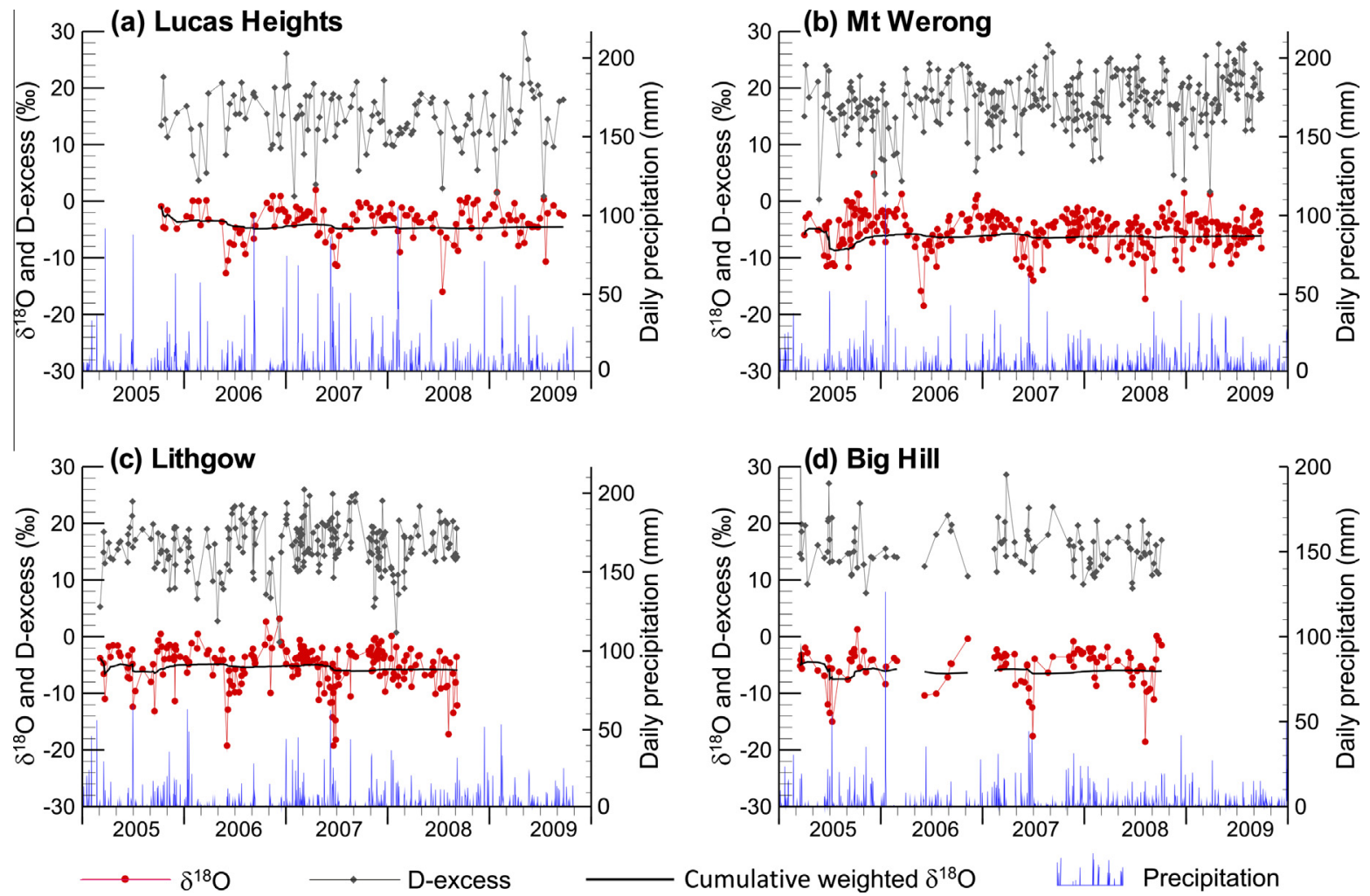

Fig. 2. Time series plots of $\delta^{18} \mathrm{O}$, D-excess, weighted average $\delta^{18} \mathrm{O}$ and daily precipitation from (a) Lucas Heights; (b) Mt Werong; (c) Lithgow and (d) Big Hill.

Table 3

Precipitation weighted average $\delta^{2} \mathrm{H}, \delta^{18} \mathrm{O}$ and D-excess and their standard error.

\begin{tabular}{|c|c|c|c|c|c|c|}
\hline \multirow{2}{*}{$\begin{array}{l}\text { Time period } \\
\text { Weighted average: }\end{array}$} & \multicolumn{4}{|c|}{ October 2005-September 2008} & \multicolumn{2}{|c|}{ October 2005-September 2009} \\
\hline & Lucas Heights & Big Hill & Lithgow & Mt Werong & Lucas Heights & Mt Werong \\
\hline$\delta^{2} \mathrm{H}(\%)$ & $-22.64 \pm 2.06$ & $-32.62 \pm 3.03$ & $-31.03 \pm 1.98$ & $-31.85 \pm 1.95$ & $-20.16 \pm 1.71$ & $-29.48 \pm 1.57$ \\
\hline$\delta^{18} \mathrm{O}(\%)$ & $-4.79 \pm 0.25$ & $-6.03 \pm 0.40$ & $-5.88 \pm 0.24$ & $-6.19 \pm 0.24$ & $-4.50 \pm 0.21$ & $-5.97 \pm 0.19$ \\
\hline D-excess $(\%)$ & $15.73 \pm 0.39$ & $15.64 \pm 0.36$ & $16.04 \pm 3.89$ & $17.66 \pm 0.28$ & $15.88 \pm 0.39$ & $18.33 \pm 0.25$ \\
\hline$n$ (used for average) & 95 & 81 & 197 & 185 & 133 & 260 \\
\hline
\end{tabular}

the coast and climate. We would recommend Lucas Heights $\left(\delta^{2} \mathrm{H}=7.99 \pm 0.15 \cdot \delta^{18} \mathrm{O}+16.0 \pm 0.8\right)$ as most representative of coastal escarpment and plain environments; Mt Werong $\left(\delta^{2} \mathrm{H}=8.08 \pm 0.07 \cdot \delta^{18} \mathrm{O}+18.6 \pm 0.5\right)$ for mid to upper Blue Mountains; Lithgow $\left(\delta^{2} \mathrm{H}=8.06 \pm 0.07 \cdot \delta^{18} \mathrm{O}+16.6 \pm 0.5\right)$, may provide the best LMWL for the eastern part of the Central Tablelands; and Big Hill $\left(\delta^{2} \mathrm{H}=8.03 \pm 0.10 \cdot \delta^{18} \mathrm{O}+15.9 \pm 0.7\right)$ for the northern part of the Southern Tablelands. It is useful to bear in mind that the difference between these equations is generally very small.

\subsection{Variability in isotopic composition}

Isotopic variations have been used to infer the atmospheric conditions at the precipitation site. For example in tropical areas the isotopic composition has been used to infer the precipitation amount and in higher latitudes the temperature at the site, although the relationships are often more complex than simple correlations (Noone and Simmonds, 2002b). To this end the relationship between the isotopes and temperature and isotopes and precipitation amount are examined as well as the seasonal behaviour of $\delta^{18} \mathrm{O}$ and $\mathrm{D}$-excess.

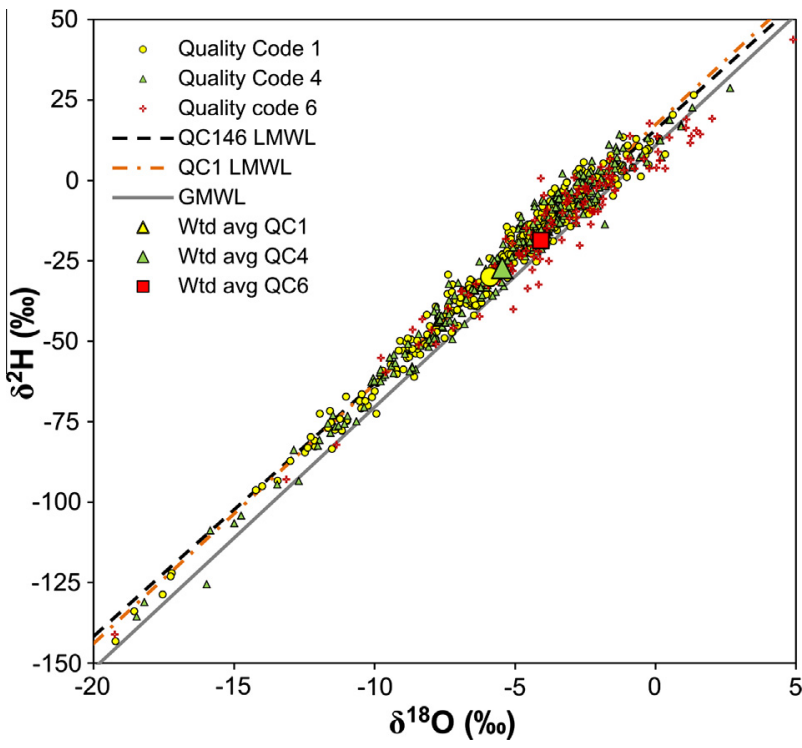

Fig. 3. The effect of quality codes on the combined $\delta^{2} \mathrm{H}$ and $\delta^{18} \mathrm{O}$ data for the four Sydney sites. Precipitation amount weighted averages for each quality code are shown, as are LMWLs using OLSR for QC1 data alone, then the entire dataset. 
Table 4

Monthly precipitation weighted $\delta^{2} \mathrm{H}$ and $\delta^{18} \mathrm{O}$ data for each site.

\begin{tabular}{|c|c|c|c|c|c|c|c|c|c|c|c|c|}
\hline \multirow[t]{2}{*}{ Month } & \multicolumn{3}{|c|}{ Lucas Heights } & \multicolumn{3}{|c|}{ Mt Werong } & \multicolumn{3}{|l|}{ Lithgow } & \multicolumn{3}{|l|}{ Big Hill } \\
\hline & $\delta^{2} \mathrm{H}(\% o)$ & $\delta^{18} \mathrm{O}(\%)$ & Precip. (mm) & $\delta^{2} \mathrm{H}(\% o)$ & $\delta^{18} \mathrm{O}(\%)$ & Precip. (mm) & $\delta^{2} \mathrm{H}(\% o)$ & $\delta^{18} \mathrm{O}(\% o)$ & Precip. (mm) & $\delta^{2} \mathrm{H}(\% o)$ & $\delta^{18} \mathrm{O}(\% o)$ & Precip. (mm) \\
\hline \multicolumn{13}{|l|}{2005} \\
\hline March & & & & & & & -37.8 & -6.52 & 53 & -21.9 & -4.81 & 52.09 \\
\hline April & & & & -21.4 & -4.83 & 71.5 & -8.0 & -2.84 & 28.6 & -4.6 & -2.38 & 9.63 \\
\hline May & & & & -22.4 & -5.09 & 9.25 & -3.7 & -2.49 & 13.8 & -31.5 & -5.96 & 3.8 \\
\hline June & & & & -46.2 & -8.18 & 71.5 & -34.9 & -6.88 & 138 & -42.3 & -7.40 & 49.8 \\
\hline July & & & & -74.3 & -11.20 & 136 & -59.7 & -9.60 & 9.8 & -65.2 & -10.22 & 72.4 \\
\hline August & & & & -40.5 & -6.93 & 46 & -26.8 & -5.72 & 24.6 & -36.4 & -6.21 & 6.1 \\
\hline September & & & & -20.5 & -4.80 & 122 & -26.2 & -5.33 & 85.4 & -11.3 & -3.46 & 86.7 \\
\hline October & -5.4 & -2.77 & 80.2 & -4.1 & -2.71 & 47 & -10.3 & -3.14 & 88.2 & -4.2 & -2.28 & 42.7 \\
\hline November & -1.3 & -1.58 & 48 & -14.0 & -3.71 & 145 & -16.7 & -4.02 & 105.8 & -34.3 & -5.52 & 55.9 \\
\hline December & -23.2 & -4.85 & 138.9 & -23.4 & -4.76 & 67.5 & -5.6 & -2.88 & 35.2 & -18.2 & -4.01 & 30 \\
\hline \multicolumn{13}{|l|}{2006} \\
\hline January & -8.0 & -2.73 & 84.1 & -28.4 & -5.55 & 246 & -23.5 & -4.78 & 192 & -47.2 & -7.81 & 118.4 \\
\hline February & -18.6 & -3.92 & 94.8 & -7.4 & -2.55 & 39 & 0.8 & -0.89 & 13.2 & -17.1 & -3.90 & 93.7 \\
\hline March & -4.6 & -2.71 & 33.3 & -6.5 & -3.43 & 25.5 & -4.1 & -2.64 & 8.2 & & & \\
\hline April & & & & -25.8 & -5.63 & 4.5 & -30.1 & -5.22 & 11.2 & & & \\
\hline May & -40.4 & -7.06 & 17.4 & -68.8 & -10.73 & 19 & -19.4 & -3.64 & 5.8 & & & \\
\hline June & -54.9 & -8.85 & 92.3 & -75.1 & -11.62 & 61 & -79.8 & -12.24 & 42.2 & -70.6 & -10.37 & 67.3 \\
\hline July & -22.4 & -5.14 & 58.1 & -50.3 & -8.60 & 75.5 & -47.6 & -8.48 & 55.8 & -62.4 & -10.05 & 57.2 \\
\hline August & -58.6 & -9.18 & 34 & -27.3 & -5.87 & 22 & -16.9 & -4.57 & 10.1 & -35.8 & -7.15 & 61.5 \\
\hline September & -24.4 & -5.40 & 171 & -29.5 & -6.08 & 71.5 & -12.6 & -3.82 & 57 & -18.9 & -4.72 & 34.8 \\
\hline October & 13.2 & -0.28 & 3.9 & 6.0 & -2.26 & 2.5 & 19.5 & 0.63 & 4 & & & \\
\hline November & -0.1 & -1.44 & 34.8 & -14.7 & -3.86 & 49.5 & -20.1 & -3.75 & 23 & 7.9 & -0.35 & 15.75 \\
\hline December & 5.0 & -1.68 & 91 & -11.2 & -3.53 & 47 & 9.9 & -0.45 & 19 & & & \\
\hline \multicolumn{13}{|l|}{2007} \\
\hline January & -3.8 & -3.51 & 94 & -19.3 & -4.75 & 93 & -23.6 & -5.24 & 81 & & & \\
\hline February & -9.4 & -3.08 & 148.4 & -18.3 & -4.45 & 134.5 & -19.5 & -4.40 & 155 & -11.1 & -3.34 & 186.44 \\
\hline March & -5.9 & -2.33 & 72.8 & -9.4 & -3.16 & 96 & -8.0 & -2.97 & 68.5 & -24.9 & -5.21 & 142.46 \\
\hline April & -22.3 & -4.71 & 65.7 & -20.5 & -4.79 & 25 & -31.6 & -5.97 & 50.5 & -32.2 & -5.96 & 17.8 \\
\hline May & -32.9 & -5.86 & 62.6 & -69.0 & -10.09 & 79.5 & -53.0 & -8.59 & 60 & -50.0 & -7.89 & 34.8 \\
\hline June & -40.1 & -7.17 & 327.7 & -59.7 & -10.17 & 151.5 & -66.9 & -10.62 & 245 & -59.2 & -9.62 & 286.3 \\
\hline July & -40.9 & -7.25 & 59.6 & -59.0 & -9.75 & 102.5 & -34.5 & -6.57 & 23 & -15.5 & -3.90 & 3 \\
\hline August & -19.3 & -4.53 & 88.4 & -44.6 & -7.80 & 69 & -51.4 & -8.51 & 70 & -32.7 & -6.34 & 35.3 \\
\hline September & -3.6 & -2.92 & 56 & -10.2 & -4.08 & 42.5 & -3.3 & -3.52 & 10 & -5.3 & -3.53 & 14.7 \\
\hline October & 3.1 & -1.11 & 19.2 & -8.6 & -2.83 & 24.5 & -6.8 & -2.87 & 26 & & & \\
\hline November & -16.9 & -4.18 & 147.6 & -24.8 & -5.32 & 156.5 & -12.5 & -3.67 & 155 & -14.8 & -3.75 & 111.3 \\
\hline December & -6.4 & -3.03 & 93 & -15.9 & -4.54 & 117 & -25.0 & -5.19 & 92.5 & -4.1 & -2.63 & 63.5 \\
\hline \multicolumn{13}{|l|}{2008} \\
\hline January & -10.5 & -2.58 & 72.7 & -29.5 & -5.43 & 87 & -35.7 & -5.76 & 112 & -8.4 & -2.59 & 55.3 \\
\hline February & -40.0 & -6.51 & 333.7 & -33.1 & -6.13 & 67 & -37.3 & -6.39 & 109 & -27.7 & -5.25 & 81.2 \\
\hline March & -3.8 & -2.06 & 56.6 & -30.5 & -5.99 & 32 & -31.8 & -5.89 & 62 & -5.5 & -2.46 & 45 \\
\hline April & -16.3 & -4.08 & 131.5 & -20.7 & -5.44 & 75.5 & -9.5 & -3.78 & 47 & -16.2 & -4.21 & 17 \\
\hline May & & & & -45.4 & -8.09 & 12 & -39.4 & -6.76 & 3 & & & \\
\hline June & -15.6 & -4.17 & 134.5 & -29.8 & -6.12 & 81 & -37.7 & -6.69 & 78 & -37.4 & -6.40 & 46 \\
\hline July & -38.8 & -6.86 & 58.3 & -31.9 & -6.53 & 68 & -30.1 & -6.00 & 35.5 & -29.5 & -5.65 & 22.3 \\
\hline August & -49.3 & -7.79 & 27.6 & -63.5 & -10.13 & 62.5 & -55.7 & -8.99 & 50.5 & -81.2 & -11.98 & 43.1 \\
\hline September & -40.6 & -6.40 & 68.4 & -53.8 & -8.94 & 113 & -47.0 & -7.88 & 88 & -47.5 & -7.59 & 40.7 \\
\hline October & -4.0 & -2.45 & 54.7 & 2.2 & -2.39 & 109 & & & & & & \\
\hline November & -20.9 & -3.96 & 38.8 & -44.1 & -7.58 & 100.5 & & & & & & \\
\hline December & -6.4 & -3.07 & 71.8 & -28.4 & -5.81 & 78.5 & & & & & & \\
\hline \multicolumn{13}{|l|}{2009} \\
\hline January & 7.7 & 0.02 & 24.6 & -10.0 & -3.71 & 34 & & & & & & \\
\hline February & -8.1 & -3.66 & 125.8 & -29.1 & -6.08 & 134 & & & & & & \\
\hline March & 0.4 & -2.04 & 42.8 & -18.2 & -4.41 & 24.5 & & & & & & \\
\hline April & -18.0 & -4.15 & 141.1 & -26.5 & -5.57 & 181 & & & & & & \\
\hline May & -13.0 & -4.33 & 87.2 & -20.4 & -5.48 & 128.5 & & & & & & \\
\hline June & -16.1 & -4.51 & 96.7 & -33.3 & -7.07 & 70.5 & & & & & & \\
\hline July & -17.4 & -2.94 & 32.6 & -21.7 & -5.72 & 76 & & & & & & \\
\hline August & 3.6 & -0.75 & 3.6 & -20.4 & -4.76 & 51 & & & & & & \\
\hline September & 2.0 & -1.92 & 27.6 & -14.6 & -4.36 & 43 & & & & & & \\
\hline
\end{tabular}

\subsubsection{Precipitation amount effect}

To determine whether an amount effect can be observed in this dataset it is necessary to establish a consistent basis for comparison of data. Many points in this dataset represent more than one precipitation event, and the mixing of events in these samples may hide an amount effect. So we extracted all data points from Mt Werong that represent a single event (defined as being separated from an adjacent event by $6 \mathrm{~h}$ or more without precipitation) and compared the regression line formed when all the data is used against that for when only the single events are used. The model fitted is defined by:

$\delta^{18} \mathrm{O}=a \mathrm{P}+b$,

where $P$ is the precipitation amount for the sample and the parameters $a$ and $b$ are determined by a least squares fit. Using all the data resulted in $a=-0.039 \pm 0.01, b=-4.68 \pm 0.23$ with an $r^{2}$ of 0.05 . 
Table 5

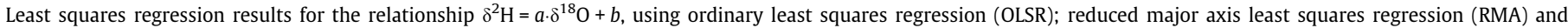

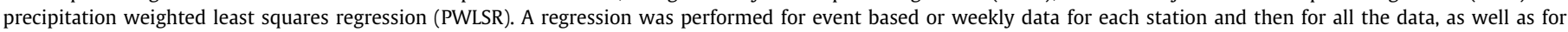

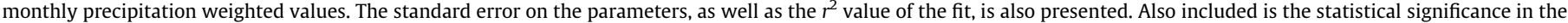
difference between the slope when using OLSR and PWLSR.

\begin{tabular}{|c|c|c|c|c|c|c|c|c|c|c|c|c|c|c|c|c|c|}
\hline \multirow[t]{2}{*}{ Quality code } & \multirow[t]{2}{*}{$N$} & \multicolumn{5}{|l|}{ OLSR } & \multicolumn{5}{|l|}{ RMA } & \multicolumn{5}{|c|}{ PWLSR } & \multirow[t]{2}{*}{ Sig } \\
\hline & & $a$ & $\sigma_{a}$ & $b$ & $\sigma_{b}$ & $r^{2}$ & $a$ & $\sigma_{a}$ & $b$ & $\sigma_{b}$ & $r^{2}$ & $a$ & $\sigma_{a}$ & $b$ & $\sigma_{b}$ & $r^{2}$ & \\
\hline \multicolumn{18}{|l|}{ Lucas Heights } \\
\hline $1,4,6$ & 130 & 7.74 & 0.15 & 13.6 & 0.7 & 0.96 & 7.91 & 0.15 & 14.3 & 0.7 & 0.96 & 7.99 & 0.15 & 16.0 & 0.8 & 0.96 & 0.24 \\
\hline 1,4 & 110 & 8.09 & 0.14 & 15.8 & 0.7 & 0.97 & 8.22 & 0.14 & 16.3 & 0.7 & 0.97 & 8.25 & 0.16 & 17.5 & 0.8 & 0.96 & 0.45 \\
\hline 1 & 68 & 7.95 & 0.20 & 16.3 & 0.9 & 0.96 & 8.11 & 0.20 & 17.0 & 0.9 & 0.96 & 8.29 & 0.22 & 18.1 & 1.1 & 0.96 & 0.25 \\
\hline \multicolumn{18}{|l|}{ Mt Werong } \\
\hline $1,4,6$ & 289 & 7.81 & 0.09 & 16.6 & 0.5 & 0.96 & 7.95 & 0.09 & 17.3 & 0.5 & 0.96 & 8.08 & 0.07 & 18.6 & 0.5 & 0.98 & 0.02 \\
\hline 1,4 & 239 & 8.17 & 0.08 & 19.5 & 0.5 & 0.98 & 8.27 & 0.08 & 20.0 & 0.5 & 0.98 & 8.18 & 0.07 & 19.5 & 0.5 & 0.98 & 0.98 \\
\hline 1 & 123 & 8.07 & 0.12 & 18.7 & 0.8 & 0.97 & 8.18 & 0.12 & 19.4 & 0.8 & 0.97 & 8.08 & 0.11 & 19.0 & 0.8 & 0.98 & 0.92 \\
\hline \multicolumn{18}{|l|}{ Lithgow } \\
\hline $1,4,6$ & 220 & 8.01 & 0.08 & 16.2 & 0.5 & 0.98 & 8.10 & 0.08 & 16.7 & 0.5 & 0.98 & 8.06 & 0.07 & 16.6 & 0.5 & 0.98 & 0.69 \\
\hline 1,4 & 184 & 8.08 & 0.09 & 16.9 & 0.5 & 0.98 & 8.16 & 0.09 & 17.3 & 0.5 & 0.98 & 8.10 & 0.08 & 17.0 & 0.5 & 0.98 & 0.85 \\
\hline 1 & 131 & 8.14 & 0.10 & 17.2 & 0.6 & 0.98 & 8.22 & 0.10 & 17.6 & 0.6 & 0.98 & 8.16 & 0.10 & 17.3 & 0.7 & 0.98 & 0.87 \\
\hline \multicolumn{18}{|l|}{ Big Hill } \\
\hline $1,4,6$ & 102 & 8.10 & 0.12 & 16.3 & 0.8 & 0.98 & 8.19 & 0.12 & 16.8 & 0.8 & 0.98 & 8.03 & 0.10 & 15.9 & 0.7 & 0.99 & 0.65 \\
\hline 1,4 & 89 & 8.07 & 0.11 & 16.0 & 0.7 & 0.99 & 8.13 & 0.10 & 16.3 & 0.7 & 0.99 & 8.03 & 0.09 & 16.1 & 0.7 & 0.99 & 0.78 \\
\hline 1 & 36 & 8.04 & 0.12 & 15.9 & 0.9 & 0.99 & 8.07 & 0.12 & 16.1 & 0.9 & 0.99 & 7.98 & 0.13 & 16.1 & 1.0 & 0.99 & 0.75 \\
\hline \multicolumn{18}{|l|}{ All } \\
\hline $1,4,6$ & 741 & 7.87 & 0.05 & 15.7 & 0.3 & 0.97 & 8.00 & 0.05 & 16.4 & 0.3 & 0.97 & 8.01 & 0.05 & 16.8 & 0.3 & 0.98 & 0.05 \\
\hline 1,4 & 622 & 8.06 & 0.05 & 17.2 & 0.3 & 0.98 & 8.15 & 0.05 & 17.7 & 0.3 & 0.98 & 8.10 & 0.05 & 17.5 & 0.3 & 0.98 & 0.54 \\
\hline 1 & 358 & 8.06 & 0.07 & 17.3 & 0.4 & 0.98 & 8.15 & 0.07 & 17.8 & 0.4 & 0.98 & 8.09 & 0.06 & 17.7 & 0.4 & 0.98 & 0.67 \\
\hline \multicolumn{18}{|l|}{ Monthly } \\
\hline ANSTO & 46 & 7.66 & 0.24 & 14.0 & 1.1 & 0.96 & 7.83 & 0.24 & 14.7 & 1.1 & 0.96 & 7.99 & 0.26 & 16.0 & 1.28 & 0.96 & 0.37 \\
\hline Mt Werong & 54 & 8.10 & 0.16 & 18.9 & 1.0 & 0.98 & 8.18 & 0.15 & 19.3 & 1.0 & 0.98 & 8.04 & 0.16 & 18.4 & 1.03 & 0.98 & 0.80 \\
\hline Lithgow & 44 & 7.67 & 0.17 & 14.4 & 1.0 & 0.98 & 7.75 & 0.16 & 14.7 & 0.9 & 0.98 & 7.71 & 0.14 & 14.5 & 0.89 & 0.99 & 0.88 \\
\hline Big Hill & 36 & 7.91 & 0.16 & 15.0 & 1.0 & 0.99 & 7.96 & 0.16 & 15.3 & 1.0 & 0.99 & 7.81 & 0.13 & 14.6 & 0.89 & 0.99 & 0.64 \\
\hline
\end{tabular}

When samples from single events only were used the result was $a=-0.035 \pm 0.014, b=-4.47 \pm 0.28$ with an $r^{2}$ of 0.04 . Even though more than one event is included in many samples, this has little impact on the $r^{2}$ value of the fit. Probably this is because most samples are still dominated by one event even if there are some small surrounding events included. The remainder of the analysis was carried out on the full data set from each site.

The relationship between precipitation amount and $\delta^{18} \mathrm{O}$ has been considered for all year and summer (December, January, February) and winter (June, July, August) separately. From Table 6b it can be seen that $40 \%$ of the variation in the $\delta^{18} \mathrm{O}$ can be explained by the precipitation amount at Lucas Heights in summer and $20 \%$ of that at Lithgow, again in summer. At Mt Werong $12 \%$ of the variation can be explained by the precipitation amount in winter (Table 6c). The value of $r^{2}$ for all other cases considered is very low.

For the data in this study the amount effect is weak as shown by small $r^{2}$ values in Table 6a-c. We examined the effect of using an exponent of 0.5 or the natural log of the sample precipitation amount (Box and Cox, 1964), as the distribution of precipitation is non-Gaussian. However, only a slight improvement was seen in the correlation (results are not presented).

In addition a de-seasoned and normalised relationship has also been considered, where the seasonal cycle has been removed by subtracting the monthly mean and dividing by the monthly standard deviation for both the $\delta^{18} \mathrm{O}$ values and the precipitation values, resulting in a more symmetrical distribution. When deseasoning is applied to the data $12 \%$ of the variation in $\delta^{18} \mathrm{O}$ can be explained by the precipitation amount effect at Lucas Heights and $10 \%$ at Lithgow, the sites at which a better $r^{2}$ value was obtained for summer (Table 6d). This is consistent with an amount effect seen primarily in summer in mid-latitudes (Dansgaard, 1964), although the relationship is poor for Mt Werong and Big Hill.

A weak relationship is seen at Mt Werong and Big Hill between precipitation amount and $\delta^{18} \mathrm{O}$ relationship in summer. On inspec- tion of the synoptic air mass history using back trajectory analysis, it was found that the $\delta^{18} \mathrm{O}$ was influenced by the conditions at the moisture source, rainout history, and also local surface temperature and humidity. To reduce the variability introduced by these factors a monthly precipitation weighted $\delta^{18} \mathrm{O}$ was generated and the analysis repeated. Using a monthly average value reduces the scatter due to variability of individual precipitation events and emphasises broader seasonal patterns. When using the monthly precipitation weighted values (when including data for all seasons) there is an improvement in $r^{2}$ for Lucas Heights with little change at the other sites (Table 6e).

\subsubsection{Temperature effect}

The linear relationship between temperature, $T$, and $\delta^{18} \mathrm{O}$ $\left(\delta^{18} \mathrm{O}=a T+b\right)$ is used in palaeo-climatological studies (Dansgaard, 1964; Fisher and Treble, 2008; Matson and Fox, 2010) and thus is a relationship that is useful to define for a particular site. For the Sydney region data the relationships between temperature and $\delta^{18} \mathrm{O}$ are shown in Table 7 for each site and then for the combined data. A better $r^{2}$ was observed for $\delta^{18} \mathrm{O}$ than for $\delta^{2} \mathrm{H}$ (results not presented), which could be attributed to such factors as the larger influence of conditions at the moisture source on $\delta^{2} \mathrm{H}$.

These results are not unexpected as weather is a complex phenomenon, and most weather systems acquire new sources of vapour along their paths that can mask the evolution of the vapour mass. The weather experienced at a meteorological station can also come from different origins, depending on the season and the track of any given storm event. Further, the in-cloud temperature of condensation (which controls fractionation) is seldom the same as the air temperature measured on the ground. For these reasons, the correlation between mean annual surface air temperature and $\delta^{18} \mathrm{O}\left(\right.$ and $\delta^{2} \mathrm{H}$ ) of precipitation for any given site is based on the average of long term monitoring data. Plotting temperature versus 
Table 6

Parameters of fit of raw $\delta^{18} \mathrm{O}$ values and precipitation amount for (a) all data; (b) summer data; (c) winter data; and (d) de-seasoned data; and (e) monthly precipitation amount averaged $\delta^{18} \mathrm{O}$ values against precipitation, together with the standard error on the parameters and the $r^{2}$ value.

\begin{tabular}{llllll}
\hline & $a$ & $\sigma_{a}$ & $b$ & $\sigma_{b}$ & $r^{2}$ \\
\hline (a) All data & & & & & \\
Lucas Heights & -0.02 & 0.01 & -2.95 & 0.34 & 0.07 \\
Mt Werong & -0.04 & 0.01 & -4.68 & 0.23 & 0.05 \\
Lithgow & -0.06 & 0.02 & -4.28 & 0.33 & 0.05 \\
Big Hill & -0.03 & 0.01 & -4.79 & 0.44 & 0.03 \\
(b) Summer & & & & & \\
Lucas Heights & -0.03 & 0.01 & -1.43 & 0.36 & 0.40 \\
Mt Werong & -0.04 & 0.01 & -3.38 & 0.34 & 0.10 \\
Lithgow & -0.08 & 0.02 & -2.72 & 0.44 & 0.20 \\
Big Hill & -0.01 & 0.01 & -3.58 & 0.59 & 0.05 \\
(c) Winter & & & & & \\
Lucas Heights & -0.01 & 0.02 & -5.84 & 0.86 & 0.00 \\
Mt Werong & -0.06 & 0.02 & -6.31 & 0.39 & 0.11 \\
Lithgow & -0.04 & 0.03 & -7.30 & 0.65 & 0.03 \\
Big Hill & -0.05 & 0.03 & -7.02 & 0.87 & 0.07 \\
(d) De-seasoned & & & & & \\
Lucas Heights & -0.35 & 0.08 & 0.00 & 0.08 & 0.12 \\
Mt Werong & -0.29 & 0.06 & 0.00 & 0.06 & 0.09 \\
Lithgow & -0.33 & 0.06 & 0.00 & 0.06 & 0.11 \\
Big Hill & -0.28 & 0.09 & 0.00 & 0.09 & 0.08 \\
(e) Monthly & & & & & \\
Lucas Heights & -0.01 & 0.00 & -3.00 & 0.50 & 0.12 \\
Mt Werong & -0.01 & 0.01 & -5.35 & 0.60 & 0.02 \\
Lithgow & -0.02 & 0.01 & -4.14 & 0.60 & 0.10 \\
Big Hill & -0.01 & 0.01 & -4.77 & 0.66 & 0.06 \\
All data & -0.01 & 0.05 & -4.41 & 0.30 & 0.05 \\
\hline
\end{tabular}

Table 7

Parameters of fit for $\delta^{18} \mathrm{O}$ dependence on temperature for (a) all data; (b) summer data; (c) winter data; and (d) de-seasoned data, and (e) monthly precipitation amount weighted values, together with the standard error on the parameters and the $r^{2}$ value.

\begin{tabular}{|c|c|c|c|c|c|}
\hline & $a$ & $\sigma_{a}$ & $b$ & $\sigma_{b}$ & $r^{2}$ \\
\hline \multicolumn{6}{|l|}{ (a) All data } \\
\hline Lucas Heights & 0.47 & 0.06 & -10.88 & 0.95 & 0.33 \\
\hline Mt Werong & 0.26 & 0.03 & -8.20 & 0.34 & 0.26 \\
\hline Lithgow & 0.34 & 0.04 & -9.32 & 0.53 & 0.26 \\
\hline Big Hill & 0.31 & 0.06 & -9.20 & 0.79 & 0.21 \\
\hline All sites & 0.31 & 0.02 & -8.87 & 0.26 & 0.27 \\
\hline \multicolumn{6}{|l|}{ (b) Summer } \\
\hline Lucas Heights & 0.44 & 0.20 & -10.89 & 3.79 & 0.13 \\
\hline Mt Werong & 0.27 & 0.08 & -9.05 & 1.55 & 0.13 \\
\hline Lithgow & 0.23 & 0.11 & -8.02 & 1.96 & 0.08 \\
\hline Big Hill & 0.01 & 0.17 & -4.07 & 3.02 & 0.00 \\
\hline All sites & 0.26 & 0.06 & -8.44 & 1.06 & 0.10 \\
\hline \multicolumn{6}{|l|}{ (c) Winter } \\
\hline Lucas Heights & 0.48 & 0.22 & -11.47 & 2.60 & 0.14 \\
\hline Mt Werong & 0.50 & 0.15 & -9.62 & 0.79 & 0.12 \\
\hline Lithgow & 0.92 & 0.24 & -14.12 & 1.70 & 0.19 \\
\hline Big Hill & 0.76 & 0.35 & -13.06 & 2.41 & 0.12 \\
\hline All sites & 0.40 & 0.08 & -9.99 & 0.58 & 0.11 \\
\hline \multicolumn{6}{|l|}{ (d) De-seasoned } \\
\hline Lucas Heights & 0.42 & 0.08 & 0.00 & 0.08 & 0.17 \\
\hline Mt Werong & 0.40 & 0.05 & 0.00 & 0.05 & 0.16 \\
\hline Lithgow & 0.34 & 0.06 & 0.00 & 0.06 & 0.12 \\
\hline Big Hill & 0.18 & 0.10 & 0.00 & 0.10 & 0.03 \\
\hline All sites & 0.35 & 0.03 & 0.00 & 0.03 & 0.13 \\
\hline \multicolumn{6}{|c|}{ (e) Monthly average } \\
\hline Lucas Heights & 0.40 & 0.08 & -9.95 & 1.23 & 0.36 \\
\hline Mt Werong & 0.29 & 0.05 & -9.20 & 0.59 & 0.42 \\
\hline Lithgow & 0.09 & 0.05 & -6.13 & 0.66 & 0.08 \\
\hline Big Hill & 0.27 & 0.08 & -8.80 & 1.09 & 0.24 \\
\hline All sites & 0.21 & 0.03 & -7.71 & 0.39 & 0.24 \\
\hline
\end{tabular}

$\delta^{18} \mathrm{O}$ at the scale of individual events generally produces a very poor correlation.

Kohn and Welker (2005) reported that for their study using the precipitation amount weighted temperature resulted in a temperature coefficient (when performing a regression of $\delta^{18} \mathrm{O}$ against temperature) that was more consistent for different lengths of time (weekly, monthly, and annual). The same analysis was undertaken using the monthly precipitation amount weighted values of $\delta^{18} \mathrm{O}$ and precipitation amount weighted temperature, $T_{\text {month }}$ (Kohn and Welker, 2005).

$T_{\text {month }}=\frac{\sum P_{i} T_{i}}{\sum P_{i}}$

where $T_{i}$ is the average temperature for sample $i$ which is calculated as the average of the air temperature measured at ground-level during the precipitation event. For the Lucas Heights site, where $15 \mathrm{~min}$ temperature data is available, the average temperature was calculated from data during the precipitation event. For the other sites, where the day's minimum and maximum temperatures were recorded, an average of the two temperatures was used.

Temperature versus $\delta^{18} \mathrm{O}$ regressions had a higher $r^{2}$ when based on monthly values instead of individual samples for sites other than Lithgow (Table 7e). This is a result of the averaging of single event variability. Furthermore, if each season was analysed separately a variation in the coefficients was observed. For Lucas Heights there was no significant difference in the slopes. For the inland sites winter is significantly different from summer and when all data is considered. However, the correlations are so low that the temperature effect can only explain a small proportion of the variability.

\subsubsection{Combined temperature and precipitation amount effect}

A multi-linear regression with both precipitation and temperature was also undertaken showing a slight improvement in the $r^{2}$ when compared with the temperature only (the coefficient, $b$, corresponding to rainfall was significant at $99 \%$ confidence level). The form of the equation was:

$\delta^{18} \mathrm{O}=a T+b P+c$.

The parameters of the fit are presented in Table 8. Using a 0.5 exponent or natural $\log$ on the predictor variables $T$ and $R$ (due to their non-normal distribution, Box and Cox, 1964), resulted in a very slight improvement of the $r^{2}$.

Multi-linear regressions explain more of the variability than single parameter regressions, but not consistently more than sum of their $r^{2}$ s. We applied the function $\delta^{18} \mathrm{O}=(a+b T) \sqrt{P}+c$ used by Fischer and Treble (2008) to incorporate seasonality into the amount effect and found the $r^{2}$ was between 0.22 and 0.28 for the different sites, which was less than that for the multi-linear regression but greater than precipitation alone. This suggests that there is a weak seasonal component to the sample precipitation amount which is confirmed by observing the data. The use of an exponent to normalise the residuals in the regression appears unnecessary at these sites as the distribution of simple linear regression errors is close to normal.

It is useful to note that when the temperature drops at Lithgow and Mt Werong to a level that results in snowfall, the temperature/ isotope relationships will cease to be linear as the snow is generally much more depleted than rain. There are only a small number of samples which include snow but these are often significantly more depleted as seen at Mt Werong in Fig. 4.

Variability that cannot be explained by temperature and precipitation amount may be explained by differences in moisture source, rainout before the site, seasonal variations in storm 
Table 8

Parameters of fit for $\delta^{18} \mathrm{O}$ dependence on temperature and precipitation for the raw data.

\begin{tabular}{llllllll}
\hline Raw data & $a$ & $\sigma_{a}$ & $b$ & $\sigma_{b}$ & \multicolumn{1}{l}{$c$} & $\sigma_{c}$ & $r^{2}$ \\
\hline Lucas Heights & 0.46 & 0.06 & -0.02 & 0.01 & -10.17 & 0.93 & 0.39 \\
Mt Werong & 0.27 & 0.03 & -0.04 & 0.01 & -7.64 & 0.35 & 0.31 \\
Lithgow & 0.14 & 0.02 & -0.07 & 0.02 & -5.79 & 0.41 & 0.17 \\
Big Hill & 0.36 & 0.06 & -0.05 & 0.01 & -8.85 & 0.75 & 0.30 \\
All sites & 0.32 & 0.02 & -0.03 & 0.00 & -8.49 & 0.26 & 0.32 \\
\hline
\end{tabular}

types/patterns and variation in raindrop evaporation (Treble et al., 2005; Barras and Simmonds, 2008).

\subsection{4. $\delta^{18} O$ seasonal effects}

The $\delta^{18} \mathrm{O}$ time series shows a seasonal variation with summer high and winter low values. Feng et al. (2009), when examining GNIP data, found that for most stations the isotopic composition varies annually. The seasonal distribution of $\delta^{18} \mathrm{O}$ was examined by a least squares fit to an annual plus a semi-annual harmonic as used by Feng et al. (2009). The fitted equation can be represented as:

$\delta^{18} \mathrm{O}=a_{0}+A \cos (2 \pi(t-\alpha))+B \cos (4 \pi(t-\beta))$,

where $t$ represents time in units of a year, $A$ is the amplitude of the annual $\delta^{18} \mathrm{O}$ variation, $\alpha$ is the phase of the annual component, and
$B$ and $\beta$ are the amplitude and phase of the semi-annual component, respectively (Feng et al., 2009). The parameters $a_{0}, A, B, \alpha, \beta$ are determined by a least squares fit. Unlike, Feng et al. (2009), who used the annual mean of $\delta^{18} \mathrm{O}$ for the offset, here the offset $a_{0}$ is determined by a least squares fit to the raw data and a value very close to the annual mean was returned by the fitting process. The fit is not symmetric with the minimum reached before winter and larger peak is seen in spring than in autumn.

The raw data, the fitted curve using harmonics and the monthly precipitation weighted $\delta^{18} \mathrm{O}$ values are presented in Fig. 4. There is little difference in the amplitude of the annual harmonics (amplitude of 2.08, 1.91, 2.37, 2.20 for Lucas Heights, Mt Werong, Lithgow and Big Hill respectively), whereas there is a larger difference in the amplitude of the semi-annual component of $1,0.79,1.42$, 1.75 , in the same order. The semi-annual component results in the variation of the peak which is seen around October. The high values observed in October are due to two factors; firstly small precipitation amounts possibly affected by evaporation below the cloud, and two large precipitation events in October 2005 and October 2008, for which the first stage of the precipitation was received at the sites with back trajectories (not included) showing moisture sourced from the ocean north-east of the sites. This is consistent with known behaviour, where high values of $\delta^{2} \mathrm{H}$ and $\delta^{18} \mathrm{O}$ in precipitation may be a result of first stage rainout or being enriched by evaporation or exchange in later stage rainout (Dansgaard, 1964). The monthly precipitation weighted $\delta^{18} \mathrm{O}$ values are
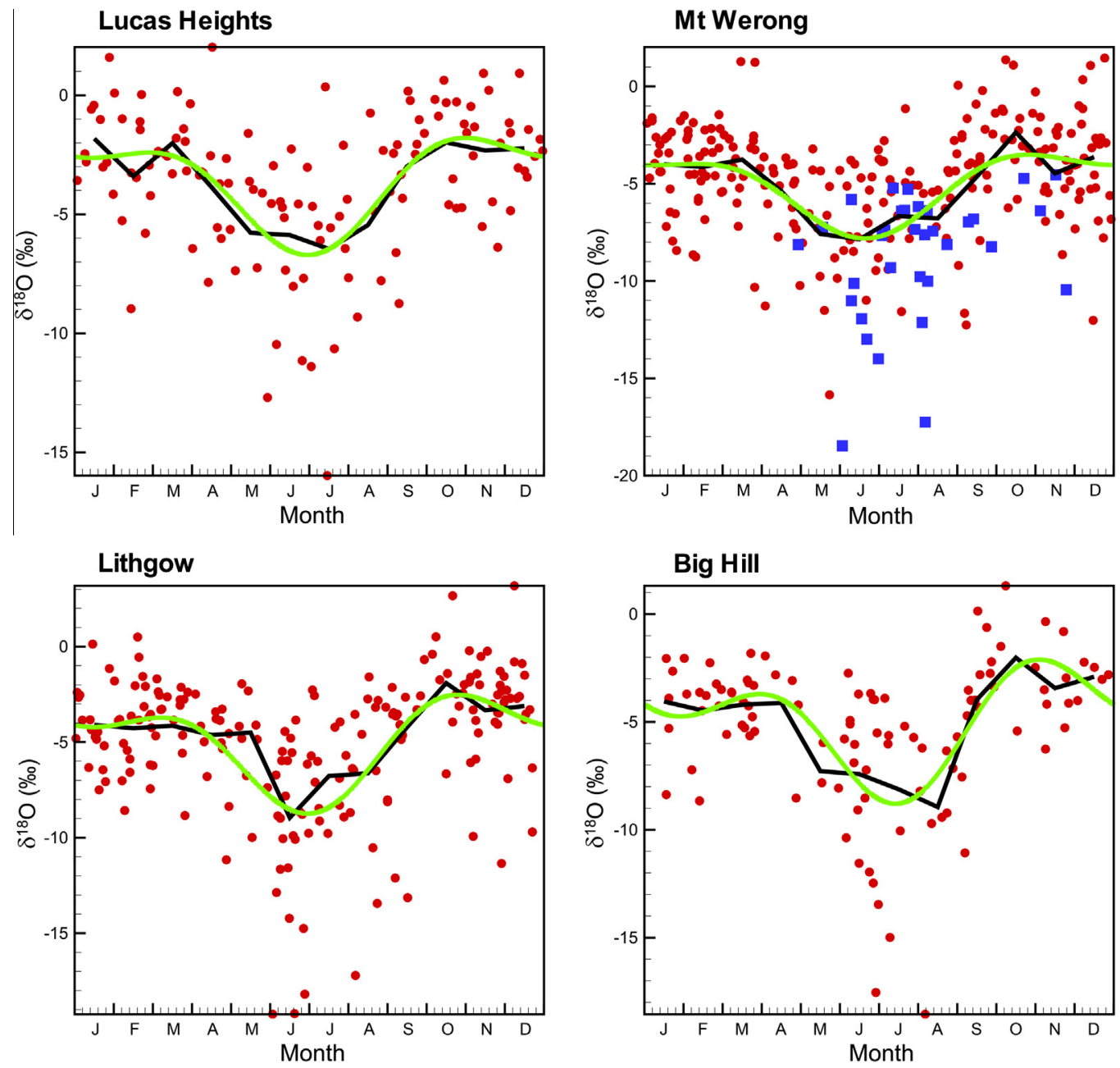

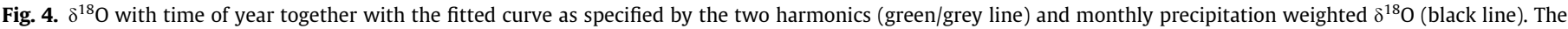
squares for Mt Werong represent samples with some snow and/or hail. 
the composite over the sampling period, and show a similar behaviour to the fitted curve using the harmonics.

\subsubsection{Deuterium excess seasonal effects}

Weighted average D-excess for sites in the Sydney region ranged from 15.45\% for Big Hill to 18.33\%o for Mt Werong (Table 3) during the study period. This is high by both Australian (average $d=12.4 \pm 1.7 \%$ ) and global standards (global average for mid-latitude GNIP sites: $d=11.4 \pm 4.8 \%$ ) and is in the range seen predominantly in countries bordering the Mediterranean Sea (Eastern Mediterranean average for GNIP sites: $d=17.4 \pm 4.1 \%$ ) where recycling of runoff is known to be high (Froehlich et al., 2002). All the Sydney sites have higher D-excess values than all known Australian sites apart from Perth $(d=15.86)$ (Liu et al., 2010), which is located on the south western coast. High D-excess values are seen throughout the year at all four sites (Fig. 5); overall we see a lower D-excess in summer attributed to an increase in evaporation of raindrops. Monthly weighted averages and harmonic fits (Eq. (6)) for D-excess show a weaker seasonality than seen for $\delta^{18} \mathrm{O}$, although this is more pronounced for Mt Werong and Lithgow with a winter maximum. Lucas Height and Big Hill show no clear maximum.

Deuterium excess is related to humidity and temperature at the moisture source (Dansgaard, 1964; Merlivat and Jouzel, 1979; Uemura et al., 2008). As a consequence, D-excess has been used to determine the temporal changes in moisture supply for a given location (e.g. Vimeux et al., 2001). In addition low D-excess is commonly associated with the evaporation of raindrops under the cloud base under warm dry conditions (Jacob and Sonntag, 1991) and also with evaporation during sampling (Froehlich et al., 2002). Orographic processes may explain the increase in D-excess between Lucas Heights and Mt Werong with evaporation of raindrops leading to enrichment of the remaining vapour as a precipitation event moves inward. Similarly, the closer proximity of the cloud base to the ground at Mt Werong may reduce evaporative enrichment of raindrops (Gat, 2010), see also discussions in Section 4.4. Neither of these factors would explain why the D-excess is unusually high at all the sites. For moisture from the Indian Ocean it has been shown that lower D-excess values can occur at the equatorial region and higher values in the sub-tropical region and in particular maximum values may occur at $30^{\circ}$ latitude, both in the northern and southern hemisphere (Froehlich et al., 2002). Other possible explanations include recycling of moisture during certain weather processes. High D-excess values could theoretically be an indication of the addition of re-evaporated moisture from surface storage of rain water being recycled into new precipitation (Dansgaard, 1964). This is seen clearly at sites at the eastern end of the Mediterranean Sea (Gat and Dansgaard, 1972) and has also been demonstrated at a more modest scale in the vicinity of the Great Lakes in north America (Gat et al., 1994). However, in the Sydney region there is no large enclosed surface water body that would be expected to contribute to precipitation on a widespread and ongoing basis. Our hypothesis is
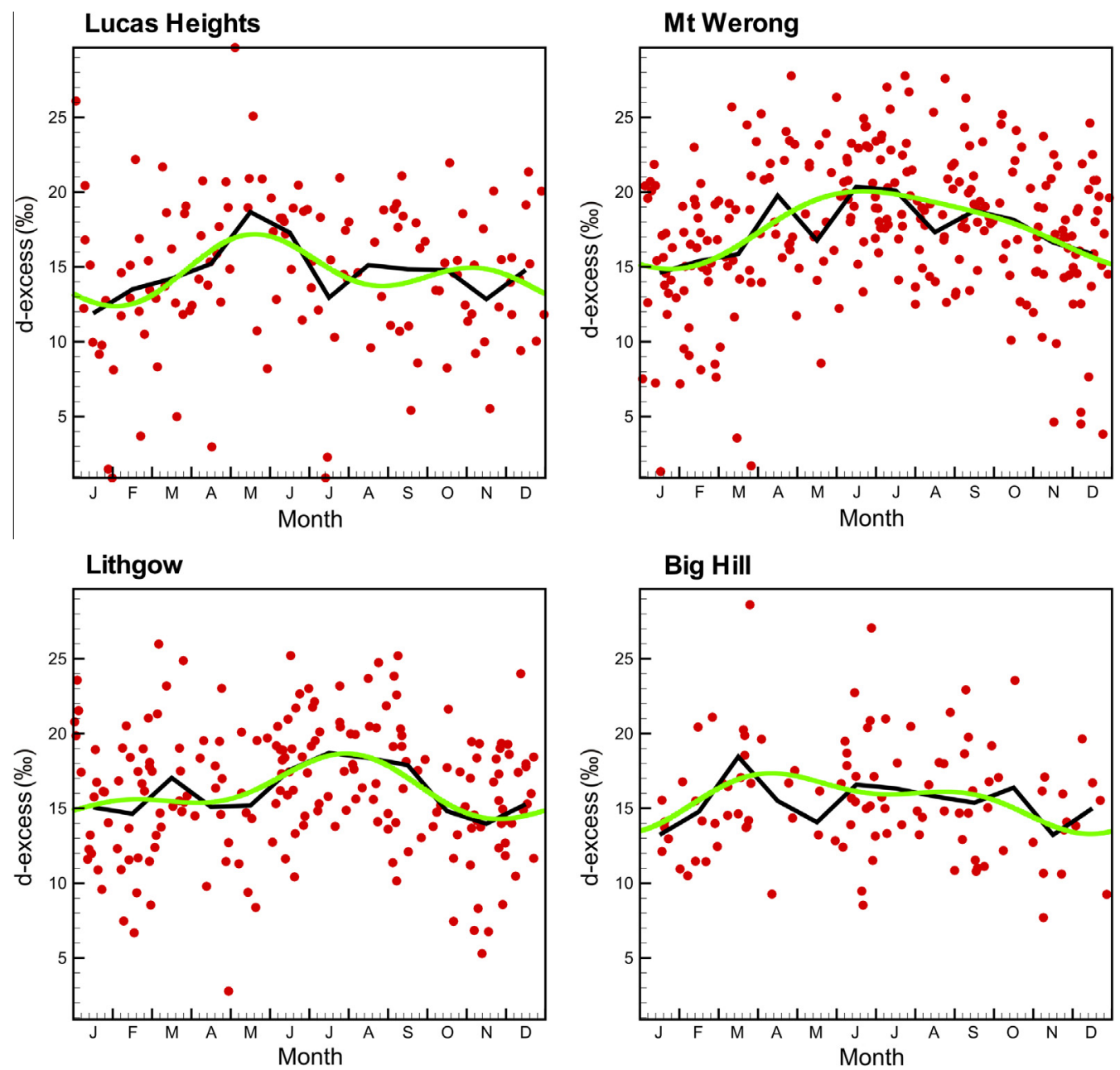

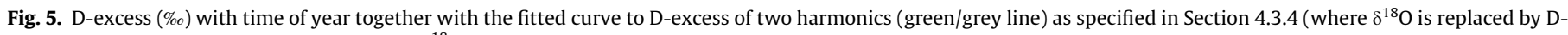
excess), and monthly precipitation weighted $\delta^{18} \mathrm{O}$ (black line). 
that recycling of moisture maybe occurring as rainfall fronts move across south eastern Australia towards Sydney (Matthews and Geerts, 1995). Low humidity often experienced in inland SE Australia would be expected to lead to a greater shift in atmospheric D-excess both during evaporation of raindrops and also in re-evaporation of surface and soil moisture, than would be seen in many other parts of the world.

When D-excess is plotted against $\delta^{18} \mathrm{O}$ and precipitation (not shown) the highest values of D-excess are seen to occur for small to moderate precipitation amounts that are not particularly depleted $\left(\delta^{18} \mathrm{O}=\sim 3-8 \%\right)$. High precipitation amounts are commonly associated with east coast low pressure systems and coastal troughs which would not be expected to have a high D-excess but may be significantly depleted.

\subsubsection{Relationships with larger scale climate drivers}

Whilst this is a relatively short dataset, it does span drought and non-drought periods so comparisons between isotopic parameters and climate indices may show some useful correlation. We compared raw, summer, winter and de-seasoned monthly values of $\delta^{2} \mathrm{H}, \delta^{18} \mathrm{O}$ and D-excess with four climate indices: ENSO SST, Southern Oscillation Index (SOI), DMI and SAM. No strong patterns emerged, however some individual correlations were observed. Winter values of $\mathrm{D}$-excess had a moderate to strong positive correlation with DMI for Mt Werong $\left(r^{2}=0.32\right)$ and Big Hill $\left(r^{2}=0.17\right)$, with Mt Werong also showing a weak to moderate positive correlation for $\delta^{2} \mathrm{H}\left(r^{2}=0.12\right)$ and $\delta^{18} \mathrm{O}\left(r^{2}=0.08\right)$. Both sites had a moderate positive correlation for the whole year also. Lucas Heights on the other hand was negatively correlated with winter DMI for $\delta^{2} \mathrm{H}$ and $\delta^{18} \mathrm{O}$ but showed a moderate to strong positive correlation for all isotopic parameters for summer. Whilst SOI had a weak to strong positive correlation with precipitation amount across all sites there was no pattern in the scattered weak correlations with isotopic parameters for annual and de-seasoned data. Various authors have found negative correlations between ENSO and $\delta^{18} \mathrm{O}$, however, these appear to be no more than an amount effect (Tindall et al., 2009; Vuille and Werner, 2005). Care should be taken when interpreting scattered correlations as they may be incidental, not based on any causal relationship.

Seasonal patterns were stronger with SOI showing strong negative correlations with $\delta^{2} \mathrm{H}$ and $\delta^{18} \mathrm{O}$ for Mt Werong and Lithgow, and weaker correlations at the other sites. Liu et al. (2010) also found periods when there was a negative correlation between the $\delta^{18} \mathrm{O}$ and SOI index for Brisbane and Melbourne.

\subsection{Comparison between stations and with other data}

Local meteoric water lines using PWLSR (Table 5) and weighted average values for each site are shown in Fig. 6. The LMWLs for Lucas Heights, Big Hill and Lithgow are very similar, but the Mt Werong LMWL has a distinctly higher D-excess. The only prior meteoric water line $\left(\delta^{2} \mathrm{H}=8.22 \cdot \delta^{18} \mathrm{O}+15.41\right)$ known for Sydney was provided by McLean et al. (2007) for the Botany Basin in the Sydney metropolitan coastal region. This is similar to the LMWL derived in this paper for Lucas Heights, albeit with a slightly higher slope but suggesting that the precipitation had a lower D-excess than observed at Lucas Heights. Jacobsen et al. (1991) also refer to a LMWL for Canberra, $\sim 100 \mathrm{~km}$ SW of Big Hill, of $\delta^{2} \mathrm{H}=8.52 \cdot \delta^{18} \mathrm{O}+15.23$ which also has a higher slope but lower D-excess than observed for Big Hill.

Individual storm events where precipitation was recorded at all sites were examined. The main influence is a coastal effect, which is clearly seen at Lucas Heights with individual event and weighted average values being significantly less depleted than the other sites.

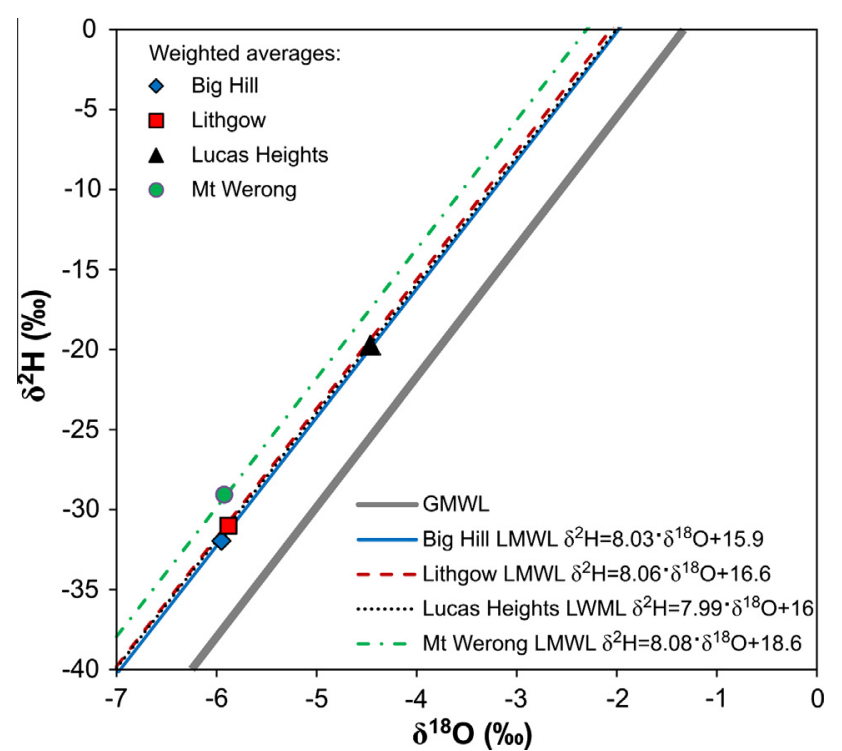

Fig. 6. LWMLs (using PWLSR) for the four sites in comparison with the GMWL. Precipitation amount weighted average $\left(\delta^{18} \mathrm{O}, \delta^{2} \mathrm{H}\right)$ also shown.

There was also a noticeable difference in the weighted average D-excess values; with the highest D-excess values seen at Mt Werong, and lowest at Lucas Heights. Higher D-excess values with higher altitude have previously been observed (Gat, 2010). Given that Mt Werong has the lowest annual average temperature and the highest altitude, and is well inland, moisture recycling and/or condensation temperature are the more likely contributors to the higher D-excess. It is interesting to note that Lithgow has a significantly lower D-excess than Mt Werong, although it is in a similar location and experiences similar weather patterns.

Re-evaporation of moisture from intercepted rainfall in the highly forested catchment surrounding Mt Werong and re-evaporation of water from Lake Burragorang were considered as possible sources of higher D-excess moisture. To explore this we considered the difference between drought (October 2005-September 2007) and non-drought (October 2007-September 2009) periods in this dataset. When D-excess for the periods are compared, Mt Werong had an increase of $2 \%$ following the drought, whereas Lucas Heights had a decrease of 1\%o. In June 2007 (Table 4) a significant and depleted rainfall event across the Sydney Region contributed to an inflow to Lake Burragorang which doubled its storage and was considered to indicate the breaking of the drought. The average D-excess of this inflow is estimated from rainfall data to be $19 \%$ which is likely to have increased the D-excess of stored water in Lake Burragorang, which was subject to significant evaporation during the drought (D-excess $\sim 5 \%$ in March 2006). If re-evaporated moisture from Lake Burragorang was influencing the composition of Mt Werong precipitation this inflow would lead to an increase in D-excess as observed.

Little groundwater stable isotope data has been published for the Sydney region. However, groundwater sampling conducted in the Upper Nepean catchment west of Mittagong, approximately halfway between Lucas Heights and Big Hill, found groundwater isotope composition averaged $\delta^{2} \mathrm{H}=-31.3 \%$ ( $\mathrm{SD}=3.4 \%$ ) and $\delta^{18} \mathrm{O}=-6.06 \%$ o $(\mathrm{SD}=0.41 \%$ ) $(d=17.2 \%$ ) (SCA and Parsons Brinckerhoff, 2006). This is very similar to the average precipitation isotope composition for the inland sites in this study. In the same report ${ }^{3} \mathrm{H}$ and ${ }^{14} \mathrm{C}$ dating show an age range from modern to $\sim 10,000$ years. There is no clear relationship between $\delta^{2} \mathrm{H}$ or $\delta^{18} \mathrm{O}$ and groundwater age although the older samples tend to be at the depleted end of the scale. This suggests that the isotopic 
composition of rainwater contributing to groundwater recharge in the southern highlands of NSW has not changed significantly over that time period.

Shallow young groundwater collected at Lucas Heights from 2007 to 2009 (Cendón et al., submitted for publication) had an average composition of $\delta^{2} \mathrm{H}=-22.9 \%$ ( $\mathrm{SD}=4.3 \%$ ) and $\delta^{18} \mathrm{O}=-4.77 \%$ $(\mathrm{SD}=0.34 \%)(d=15.3 \%)$ which is a little more depleted than the weighted average precipitation for Lucas Heights. Groundwaters with a slower response to precipitation, which may more closely approximate the longer term groundwater composition, were generally more depleted with a lower D-excess $\left(\delta^{2} \mathrm{H}=-26.2 \%\right.$ $\left(\mathrm{SD}=2.1 \%\right.$ ),$\delta^{18} \mathrm{O}=-4.95 \%$ ( $\mathrm{SD}=0.21 \%$ ),$d=13.4 \%$ ). This provides evidence that the pattern of large precipitation events being more depleted but with a lower D-excess is a long-term one, not particular to our study.

\section{Conclusions}

This paper presents the first dataset of $\delta^{2} \mathrm{H}$ and $\delta^{18} \mathrm{O}$ in precipitation for the Sydney Basin region of Australia and analyses 3-4 years of event based or weekly data for four sites. Monthly values, weighted averages and LMWLs are presented for use in hydrological applications in the region. A key finding is that precipitation in the Sydney Basin is isotopically different from the nearest GNIP sites with a significantly higher D-excess. This confirms the importance of defining the isotopic composition of precipitation and the LMWL for this region based on local data. For the Sydney Basin as a whole we recommend an overall LMWL of $\delta^{2} \mathrm{H}=8.01 \pm$ $0.05 \cdot \delta^{18} \mathrm{O}+16.8 \pm 0.3$ based on PWLSR for all data in this study. LMWLs published for Canberra and the Botany Basin indicate a lower D-excess than observed during this study, however the data underpinning these regressions has not been published.

High D-excess values for all sites appear likely to be the result of low humidity at the sea surface during evaporation at mid latitude sources, however recycling of moisture either locally or along a moisture transport trajectory may also be an important factor in the isotopic composition of rainfall in this region. Lake Burragorang has been identified as a possible local source of recycled moisture contributing to Mt Werong's particularly high D-excess values.

A clear coastal effect was observed at Lucas Heights which has significantly less depleted precipitation relative to the three inland sites. For single parameter regressions based on individual samples, in summer we see an amount affect, particularly at Lucas Heights and Lithgow, but little temperature effect. In winter we see a slight temperature effect but less amount effect. In general we see slightly better correlations if we take the full year data set largely because of the wider range of temperatures included. Regressions based on monthly composites, precipitation and precipitation weighted temperature show significantly stronger correlations. Combining precipitation amount and temperature in a single multi-linear regression resulted in almost identical coefficients for precipitation and temperature as those when the regression was applied separately.

On-going work involves back trajectory modelling and classification of synoptic conditions for precipitation events, with the objective of revealing any relationships that may exist between moisture sources and meteorological processes and the $\delta^{2} \mathrm{H}$ and $\delta^{18} \mathrm{O}$ composition of precipitation. Sampling is continuing at Mt Werong and Lucas Heights where the sampling frequency has been increased to daily.

\section{Acknowledgements}

We are indebted to David Stone for establishing this sampling network and to Stan Phillips, Bob Cullen, Judy Blair and Peter Davy for collecting the samples in their own time. At ANSTO, we thank Suzanne Hollins for getting the funding to get samples analysed and for reading this manuscript; Chris Dimovski and Tim Morrison for sampling; Nathan Butterworth for sampler testing; Stuart Hankin for help with spatial data; Craig Thompson for sampler design and construction, Leisa Dyer and staff from Environmental Monitoring for met data. Martin Gilmour and James Ray from Sydney Catchment Authority were very helpful in providing rainfall data. Finally, the comments of two anonymous reviewers have greatly improved this text.

\section{References}

Araguas-Araguas, L., Froehlich, K., Rozanski, K., 2000. Deuterium and oxygen-18 isotope composition of precipitation and atmospheric moisture. Hydrol. Process. 14, 1341-1355.

Argiriou, A.A., Lykoudis, S., 2006. Isotopic composition of precipitation in Greece. J. Hydrol. 327, 486-495.

Baldini, L.M., McDermott, F., Baldini, J.U.L., Fischer, M.J., Möllhoff, M., 2010. An investigation of the controls on Irish precipitation $\delta^{18} \mathrm{O}$ values on monthly and event timescales. Clim. Dyn. 35, 977-993.

Barras, V., Simmonds, I., 2008. Synoptic controls upon $\delta^{18} \mathrm{O}$ in southern Tasmanian precipitation. Geophys. Res. Lett. 35, L02707. http://dx.doi.org/10.1029/ 2007GL031835

Barras, V., Simmonds, I., 2009. Observation and modeling of stable water isotopes as diagnostics of rainfall dynamics over southeastern Australia. J. Geophys. Res. 114, D23308. http://dx.doi.org/10.1029/2009JD012132.

Box, G.E.P., Cox, D.R., 1964. An analysis of transformations. J. R. Stat. Soc. B: Met. 26, 211-252.

Cendón, D.I., Hughes, C.E., Harrison, J.J., Hankin, S.I., Johansen, M.P., Wong, H., Payne, T.E., Rowling, B., Vine, M., Wilsher, K., Guinea, A., Thiruvoth, S., submitted for publication. Identification of sources and processes involving a low-level radioactive waste site adjacent to landfills using groundwater hydrogeochemistry and isotopes. Appl. Geochem.

Dansgaard, W., 1964. Stable isotopes in precipitation. Tellus 16, 436-468.

Feng, X., Faiia, A.M., Posmentier, E.S., 2009. Seasonality of isotopes in precipitation: a global perspective. J. Geophys. Res. 114, D08116. http://dx.doi.org/10.1029/ 2008JD011279.

Fisher, M.J., Treble, P.C., 2008. Calibrating climate $-\delta^{18} \mathrm{O}$ regression models for the interpretation of high-resolution speleothem $\delta^{18} \mathrm{O}$ time series. J. Geophys. Res. 113, D17103. http://dx.doi.org/10.1029/2007JD009694.

Froehlich, K., Gibson, J.J., Aggarwal, P.K., 2002. Deuterium excess in precipitation and its climatological significance. In: Proceedings of Study of Environmental Change Using Isotope Techniques, IAEA, Vienna, IAEA-CSP-13/P, pp. 54-66.

Gammons, C.H., Poulson, S.R., Pellicori, D.A., Reed, P.J., Roesler, A.J., Petrescu, E.M., 2006. The hydrogen and oxygen isotopic composition of precipitation, evaporated mine water, and river water in Montana, USA. J. Hydrol. 328, 319-330.

Gat, J.R., 2010. Isotope Hydrology: A Study of the Water Cycle. Imperial College Press, London.

Gat, J.R., Dansgaard, W., 1972. Stable isotopes survey of the freshwater occurrences in Israel and the Jordan Rift Valley. J. Hydrol. 16, 177-211.

Gat, J.R., Bowser, C., Kendall, C., 1994. The contribution of evaporation from the Great Lakes to the continental atmosphere: estimate based on stable isotope data. Geophys. Res. Lett. 21, 557-560.

Gedzelman, S., Lawrence, J., Gamache, J., Black, M., Hindman, E., Black, R., Dunion, J., Willoughby, H., Zhang, X., 2003. Probing hurricanes with stable isotopes of rain and water vapor. Mon. Weather Rev. 131, 1112-1127.

Gröning, M., Lutz, H.O., Roller-Lutz, Z., Kralik, M., Gourcy, L., Pöltenstein, L., 2012. A simple rain collector preventing water re-evaporation dedicated for $\delta^{18} \mathrm{O}$ and $\delta^{2} \mathrm{H}$ analysis of cumulative precipitation samples. J. Hydrol. 448-449, 195-200.

Ho, M., Kiem, A.S., Verdon-Kidd, D.C., 2012. The Southern Annular Mode: a comparison of indices. Hydrol. Earth Syst. Sci. 16, 967-982. http://dx.doi.org/ 10.5194/hess-16-967-2012.

Hughes, C.E., Crawford, J., 2012. A new precipitation weighted method for determining the meteoric water line for hydrological applications demonstrated using Australian and global GNIP data. J. Hydrol. 464-465 344-351.

International Atomic Energy Agency, 1992. Statistical Treatment of Data on Environmental Isotopes in Precipitation. Technical Reports Series No. 331, IAEA, Vienna.

IAEA/WMO, 2006. Global Network of Isotopes in Precipitation. The GNIP Database. <http://www.iaea.org/water>.

Jacob, H., Sonntag, C., 1991. An 8-year record of the seasonal variation of ${ }^{2} \mathrm{H}$ and ${ }^{18} \mathrm{O}$ in atmospheric water vapour and precipitation at Heidelberg, Germany. Tellus 43B, 291-300.

Jacobsen, G., Jankowski, J., Abell, R.S., 1991. Groundwater and surface water interaction at Lake George, New South Wales. BMR J. Aust. Geol. Geophys. 12, 161-190.

Kohn, M.J., Welker, J.M., 2005. On the temperature correlation of $\delta^{18} \mathrm{O}$ in modern precipitation. Earth Planet. Sci. Lett. 231, 87-96. 
Liu, J., Fu, G., Song, X., Charles, S.P., Zhang, Y., Han, D., Wang, S., 2010. Stable isotopic compositions in Australian precipitation. J. Geophys. Res. 115, D23307. http:// dx.doi.org/10.1029/2010JD014403.

Matson, S., Fox, D., 2010. Stable isotopic evidence for terrestrial latitudinal climate gradients in the Late Miocene of the Iberian Peninsula. Palaeogeogr. Palaeoclimatol. Palaeoecol. 287, 28-44.

Matthews, C., Geerts, B., 1995. Characteristic thunderstorm distribution in the Sydney area. Aust. Meteorol. Mag. 44, 127-138.

McLean, W., David, K., Jankowski, J., 2007. Surface water-groundwater interaction in the Nattai River catchment, New South Wales, Australia. In: Ribeiro, L et al. (Eds.), Proceedings of the XXXV Congress of the International Association of Hydrogeologists, Groundwater and Ecosystems, IAH, Paper 528 (ISBN: 978-98995297-3-1).

Meneghini, B., Simmonds, I., Smith, I.N., 2007. Association between Australian rainfall and the Southern Annular Mode. Int. J. Climatol. 27, 109-121.

Merlivat, L., Jouzel, J., 1979. Global climatic interpretation of the deuterium-oxygen 18 relationship for precipitation. J. Geophys. Res. 84 (C8), 5029-5033.

Noone, D., Simmonds, I., 2002a. Associations between $\delta^{18} \mathrm{O}$ of Water and climate Parameters in a Sumulation of Atmospheric Circulation for 1979-1995. J. Climate 15, 3150-3169.

Noone, D., Simmonds, I., 2002b. Annular variations in moisture transport mechanisms and the abundance of $\delta^{18} \mathrm{O}$ in Antarctic snow. J. Geophys. Res. 107, 4742. http://dx.doi.org/10.1029/2002JD002262.

Risbey, J.S., Pook, M.J., McIntosh, P.C., Wheeler, M.C., Hendon, H.H., 2009. On the remote drivers of rainfall variability in Australia. Mon. Weather Rev. 137, 3233 3253.

Rozanski, K., Sonntag, G., Munnich, K.O., 1982. Factors controlling stable isotope composition of European precipitation. Tellus 34, 142-150.

Rozanski, K., Araguás-Araguás, L., Gonfiantini, R., 1993. Isotopic patterns in modern global precipitation. In: Swart P.K. et al. (Eds.), Climate Change in Continental Isotopic Records. Geophys. Monogr. Ser. 78, AGU, Washington, DC, pp. $1-36$.
Sydney Catchment Authority, Parsons-Brinckerhoff, 2006. Hydrochemical and Environmental Isotope Sampling Program - Upper Nepean Groundwater Investigation Sites. Sydney Catchment Authority, Sydney, GW011-06-06V1.

Simpkins, W.W., 1995. Isotopic composition of precipitation in central Iowa. J. Hydrol. 172, 185-207.

Speer, M.S., Wiles, P., Pepler, A., 2009. Low pressure systems off the New South Wales coast and associated hazardous weather: establishment of a database. Aust. Meteorol. Oceanogr. J. 58, 29-39.

Speer, M.S., Leslie, L.M., Fierro, A., 2011. Australian east coast rainfall decline related to large scale climate drivers. Clim. Dyn. 36, 1419-1429. http://dx.doi.org/ 10.1007/s00382-009-0726-1.

Tindall, J.C., Valdes, P.J., Sime, L.C., 2009. Stable water isotopes in HadCM3: isotopic signature of El Nino-Southern Oscillation and the tropical amount effect. J. Geophys. Res. 114, D04111.

Treble, P.C., Budd, W.F., Hope, P.K., Rustomji, P.K., 2005. Synoptic-scale climate patterns associated with rainfall $\delta^{18} \mathrm{O}$ in southern Australia. J. Hydrol. 302, 270-282.

Uemura, R., Matsui, Y., Yoshimura, K., Motoyama, H., Yoshida, N., 2008. Evidence of deuterium excess in water vapour as an indicator of ocean surface conditions. J. Geophys. Res. 113, D19114. http://dx.doi.org/10.1029/2008JD010209.

Verdon, D.C., Franks, S.W., 2005. Indian Ocean sea surface temperature variability and winter rainfall: Eastern Australia. Water Resour. Res. 41, W09413. http:// dx.doi.org/10.1029/2004WR003845.

Vimeux, F., Masson, V., Jouzel, J., Petit, J.R., Steig, E.J., Stievenard, M., Vaikmae, R., White, J.W.C., 2001. Holocene hydrological cycle changes in the Southern Hemisphere documented in East Antarctic deuterium excess records. Clim. Dyn. 17, 503-513.

Vuille, M., Werner, M., 2005. Stable isotopes in precipitation recording South American summer monsoon and ENSO variability: observations and model results. Clim. Dyn. 25, 401-413.

Yamanaka, T., Tsujimura, M., Oyunbaatar, D., Davaa, G., 2007. Isotopic variation of precipitation over eastern Mongolia and its implication for the atmospheric water cycle. J. Hydrol. 333, 21-34. 